\title{
High particulate organic carbon export during the decline of a vast diatom bloom in the Atlantic sector of the Southern Ocean
}

\author{
Montserrat Roca-Martí ${ }^{a}{ }^{*}$, Viena Puigcorbé ${ }^{a}$, Morten H. Iversen ${ }^{b, c, d}$, \\ Michiel Rutgers van der Loeff ${ }^{\mathrm{b}}$, Christine Klaas ${ }^{\mathrm{b}}$, Wee Cheah ${ }^{\mathrm{b}, \mathrm{e}}$, Astrid Bracher ${ }^{\mathrm{b}, \mathrm{f}}$, \\ Pere Masqué ${ }^{\mathrm{a}, \mathrm{g}, \mathrm{h}, *}$ \\ ${ }^{a}$ Institut de Ciència i Tecnologia Ambientals E' Departament de Física, Universitat Autònoma de Barcelona, 08193 Bellaterra, Spain \\ ${ }^{\mathrm{b}}$ Alfred Wegener Institute for Polar and Marine Research, 27570 Bremerhaven, Germany \\ ${ }^{\mathrm{c}}$ Faculty of Geosciences and MARUM, University of Bremen, 28359 Bremen, Germany \\ ${ }^{\mathrm{d}}$ Helmholtz Young Investigator Group SEAPUMP, Alfred Wegener Institute for Polar and Marine Research, 27570 Bremerhaven, Germany \\ ${ }^{\text {e }}$ Research Center for Environmental Changes, Academia Sinica, Taipei 115, Taiwan \\ ${ }^{\mathrm{f}}$ Institute of Environmental Physics, University of Bremen, 28359 Bremen, Germany \\ ${ }^{g}$ Oceans Institute and School of Physics, The University of Western Australia, Crawley, WA 6009, Australia \\ ${ }^{\mathrm{h}}$ School of Natural Sciences and Centre for Marine Ecosystems Research, Edith Cowan University, Joondalup, WA 6027, Australia
}

\section{A R T I C L E I N F O}

\section{Available online 18 December 2015}

Keywords:

Particulate organic carbon export

Diatoms

Bloom

Southern Ocean

Thorium

Sediment traps

Biological pump

Export efficiency

Transfer efficiency

\begin{abstract}
A B S T R A C T
Carbon fixation by phytoplankton plays a key role in the uptake of atmospheric $\mathrm{CO}_{2}$ in the Southern Ocean. Yet, it still remains unclear how efficiently the particulate organic carbon (POC) is exported and transferred from ocean surface waters to depth during phytoplankton blooms. In addition, little is known about the processes that control the flux attenuation within the upper twilight zone. Here, we present results of downward $\mathrm{POC}$ and particulate organic nitrogen fluxes during the decline of a vast diatom bloom in the Atlantic sector of the Southern Ocean in summer 2012 . We used thorium-234 $\left({ }^{234} \mathrm{Th}\right)$ as a particle tracer in combination with drifting sediment traps (ST). Their simultaneous use evidenced a sustained high export rate of ${ }^{234} \mathrm{Th}$ at $100 \mathrm{~m}$ depth in the weeks prior to and during the sampling period. The entire study area, of approximately $8000 \mathrm{~km}^{2}$, showed similar vertical export fluxes in spite of the heterogeneity in phytoplankton standing stocks and productivity, indicating a decoupling between production and export. The POC fluxes at $100 \mathrm{~m}$ were high, averaging $26 \pm 15 \mathrm{mmol} \mathrm{C} \mathrm{m}{ }^{-2} \mathrm{~d}^{-1}$, although the strength of the biological pump was generally low. Only $<20 \%$ of the daily primary production reached $100 \mathrm{~m}$, presumably due to an active recycling of carbon and nutrients. Pigment analyses indicated that direct sinking of diatoms likely caused the high POC transfer efficiencies $(\sim 60 \%)$ observed between 100 and $300 \mathrm{~m}$, although faecal pellets and transport of POC linked to zooplankton vertical migration might have also contributed to downward fluxes.
\end{abstract}

(c) 2015 Elsevier Ltd. All rights reserved.

\section{Introduction}

The Southern Ocean is an important sink for atmospheric $\mathrm{CO}_{2}$ accounting for about $15-20 \%$ of the global oceanic uptake (Gruber et al., 2009; Takahashi et al., 2002), with a significant contribution from phytoplankton that fix $\mathrm{CO}_{2}$ to organic carbon (Hauck et al., 2013). However, the strength and efficiency of the biological pump (i.e. export efficiency and transfer efficiency, respectively), as well

\footnotetext{
*Corresponding authors at: Institut de Ciència i Tecnologia Ambientals \& Departament de Física, Universitat Autònoma de Barcelona, 08193 Bellaterra, Spain. Tel.: +34 935811191.

E-mail addresses: Montserrat.Roca.Marti@uab.cat (M. Roca-Martí), pere.masque@uab.cat (P. Masqué).
}

as their controlling factors are poorly understood, especially during phytoplankton blooms (Buesseler and Boyd, 2009).

The export efficiency (i.e. the fraction of production that is exported from the upper ocean, usually taken as the base of the euphotic zone or $100 \mathrm{~m}$ ) is low in much of the global ocean $(<5-$ $10 \%$ ), but it is typically about $50 \%$ for blooms at high latitudes (Buesseler, 1998). However, previous studies have reported lower export efficiencies during high-productive events in the Southern Ocean (Jacquet et al., 2011; Planchon et al., 2015; Rutgers van der Loeff et al., 1997; Savoye et al., 2008). Furthermore, iron-fertilised blooms in the Southern Ocean show high variability in the fraction of production being exported from the ocean surface. As an example, during SOFeX-South $\left(66^{\circ} \mathrm{S}\right)$ the export efficiency was low $(<10 \%$, Buesseler et al., 2005), while during EIFEX it was approximately $60 \%$, indicating a very strong biological pump 
(Smetacek et al., 2012). A number of factors may explain the differences observed in export efficiencies, including phytoplankton community composition and study time frame. Diatoms are key exporters of carbon from the ocean surface to deep waters and sediments, and hence play an essential role in reducing the $\mathrm{CO}_{2}$ content in the atmosphere (Smetacek, 1999). Previous studies have shown that very low macronutrient concentrations, specifically of silicic acid, prevent the development of diatom blooms in benefit of flagellates, resulting in low particulate organic carbon (POC) export fluxes from the ocean surface (Jacquet et al., 2011; Martin et al., 2013). Further, diatoms in the Southern Ocean contribute differently to POC export according to their life cycle strategy in which the degree of silicification is relevant (Assmy et al., 2013; Quéguiner, 2013). Moreover, since export lags production, the time scale of the studies may often be too short to quantitively estimate the strength of the biological pump during bloom events (Buesseler et al., 2004; Charette and Buesseler, 2000).

The transfer efficiency (i.e. the fraction of shallow export that is transferred to depth) indicates the attenuation of the flux that takes place within a certain depth range. While it is known that the attenuation of POC fluxes is sharpest in the upper twilight zone, i.e. 100-300 $\mathrm{m}$ below the euphotic zone depth, our understanding of the processes affecting sinking particles throughout this layer is still poor (Buesseler and Boyd, 2009). The vertical flux of organic matter throughout the water column is dominated by large particles such as marine snow and faecal pellets (Ebersbach et al., 2011; Fowler and Knauer, 1986; Laurenceau-Cornec et al., 2015) that can be attenuated to a large extent by zooplankton and microbial degradation (Giering et al., 2014; Iversen et al., 2010; Kiørbe, 2000; Smith et al., 1992). However, packaging of slowly sinking phytoplankton cells into large faecal pellets may play a key role in increasing the export and transfer efficiencies in the Southern Ocean (Cavan et al., 2015; Le Moigne et al., 2014). Mineral ballasting also appears to alter the efficiency by which POC is transported to depth (e.g. Iversen and Robert, 2015; Klaas and Archer, 2002).

Thorium-234 $\left({ }^{234} \mathrm{Th}\right.$, half-life $\left.=24.1 \mathrm{~d}\right)$ is widely used as a particle tracer, mainly of POC, since it is particle reactive and its halflife allows studying events occurring over short time scales, ranging from days to weeks, such as phytoplankton blooms (e.g. Buesseler et al., 1992; Rutgers van der Loeff et al., 1997). A deficit of ${ }^{234} \mathrm{Th}$ with respect to its parent ${ }^{238} \mathrm{U}$ is typically found in the upper ocean. Once the ${ }^{234} \mathrm{Th}$ downward flux at a specific depth is quantified, this flux can be converted to POC and particulate organic nitrogen (PON) fluxes by determining the $\mathrm{POC} /{ }^{234} \mathrm{Th}$ and $\mathrm{PON} /{ }^{234} \mathrm{Th}$ ratios, respectively, in sinking particles (Buesseler et al., 2006; Cochran and Masqué, 2003).

This study focuses on the decline of a vast diatom bloom that occurred in the Antarctic Circumpolar Current (ACC) region of the Southern Ocean (around $51^{\circ} \mathrm{S} 13^{\circ} \mathrm{W}$ ) during the late austral summer in 2012. Our objectives were to evaluate the export efficiency and transfer efficiency of POC between 100 and $300 \mathrm{~m}$, as well as identify the main mechanisms that had an influence on particle fluxes. Particle fluxes were quantified by means of two different techniques, as highly recommended given the uncertainties associated with each collection method (e.g. Puigcorbé et al., 2015; Turner, 2015). We used the disequilibrium between the natural radionuclides ${ }^{234} \mathrm{Th}$ and ${ }^{238} \mathrm{U}$ to determine the export fluxes of POC and PON in parallel with the use of surface-tethered drifting sediment traps. Export fluxes were related to the evolution of chlorophyll $a$ (Chl-a) and POC concentrations in the water column, as well as to pigments in sinking particles, following the decline of the bloom during three weeks. Net primary production (NPP) measured during the same cruise (Hoppe et al., 2017) was used to assess the export efficiency.

\section{Methods}

\subsection{Study area}

Samples were collected from 29 January to 17 February 2012 during the ANT-XXVIII/3 expedition in the Atlantic sector of the Southern Ocean (7 January-11 March, 2012; R/V Polarstern; WolfGladrow, 2013). The sampling was carried out to study a massive bloom with high spatial and temporal resolution over an area of about $8000 \mathrm{~km}^{2}$ located between the Antarctic Polar Front (APF) and the Southern Polar Front (SPF; Leach et al., 2017 and Strass et al., 2017). Time-series measurements of ${ }^{234} \mathrm{Th}$, POC, PON, Chl-a, other pigments and NPP were carried out at a station located in the centre of the study area at $51.21^{\circ} \mathrm{S} 12.67^{\circ} \mathrm{W}$ (hereafter "central station", indicated by a ' $\mathrm{C}$ ' in front of the station number). The location and sampling dates of the stations sampled for ${ }^{234} \mathrm{Th}$, POC and PON fluxes are given in Fig. 1 and Table 1.

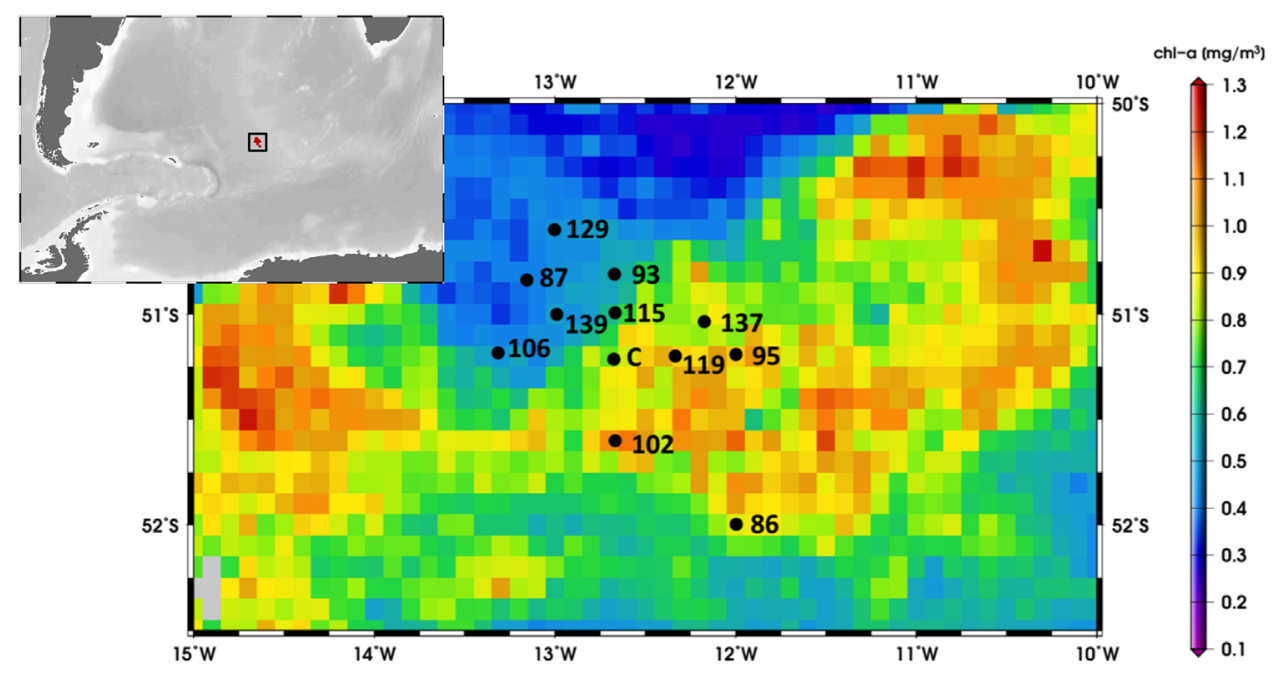

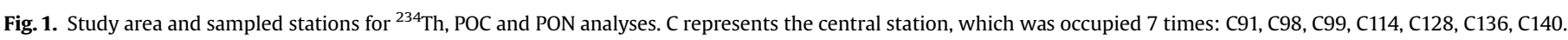

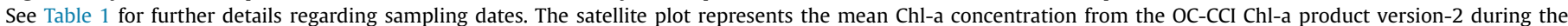
sampling period (29 January to 17 February 2012). 


\subsection{Total $^{234}$ Th and ${ }^{238} U$}

Total ${ }^{234} \mathrm{Th}$ activities were determined from $4 \mathrm{~L}$ seawater samples obtained from Niskin bottles attached to a CTD rosette. Samples were collected from 11 to 13 depths down to $500-750 \mathrm{~m}$ at 14 stations, with the highest resolution in the upper $200 \mathrm{~m}$ of the water column. Three seawater profiles were taken at the central station on 3, 12 and 17 February (C91, C128, C140, respectively). In addition, replicates of deep samples $(2500 \mathrm{~m})$ were collected for calibration purposes (Rutgers van der Loeff et al., 2006). The samples were processed according to the $\mathrm{MnO}_{2}$ co-precipitation technique (Buesseler et al., 2001b), using ${ }^{230} \mathrm{Th}$ as a chemical yield tracer (Pike et al., 2005). The precipitates were filtered through QMA quartz fibre filters, dried overnight at $50{ }^{\circ} \mathrm{C}$ and prepared for beta counting. The counting was done on board using low background beta counters (Risø National Laboratories, Denmark). Samples were re-measured after 10 months to quantify the background counts. All filters were processed to determine ${ }^{230}$ Th by inductively coupled plasma mass spectrometry (ICP-MS) using ${ }^{229}$ Th as an internal standard. Briefly, filters were spiked with ${ }^{229} \mathrm{Th}$ and precipitates were dissolved in $10 \mathrm{~mL}$ of $8 \mathrm{M} \mathrm{HNO}_{3} /$ $10 \% \mathrm{H}_{2} \mathrm{O}_{2}$ solution. Samples were sonicated for $30 \mathrm{~min}$ before allowing them to rest for at least $6 \mathrm{~h}$. Prior to the ICP-MS analyses the samples were filtered through Acrodisc $0.2 \mu \mathrm{m}$ syringe filters

Table 1

Location and date of the stations sampled for ${ }^{234} \mathrm{Th}$, POC and PON analyses. C indicates the central station.

\begin{tabular}{llll}
\hline Station & Lon. $\left({ }^{\circ} \mathrm{W}\right)$ & Lat. $\left({ }^{\circ} \mathrm{S}\right)$ & Date $(2012)$ \\
\hline 86 & 12.00 & 52.00 & $29-30 \mathrm{Jan}$. \\
87 & 13.16 & 50.84 & $2-3 \mathrm{Feb}$. \\
93 & 12.67 & 50.81 & $4 \mathrm{Feb}$. \\
95 & 12.00 & 51.19 & $5 \mathrm{Feb}$. \\
102 & 12.67 & 51.60 & $7 \mathrm{Feb}$. \\
106 & 13.31 & 51.18 & $7 \mathrm{Feb}$. \\
115 & 12.67 & 50.99 & $9 \mathrm{Feb}$. \\
119 & 12.33 & 51.20 & $10 \mathrm{Feb}$. \\
129 & 13.00 & 50.60 & $13 \mathrm{Feb}$. \\
137 & 12.17 & 51.04 & $14-15 \mathrm{Feb}$. \\
139 & 12.99 & 51.00 & $15-16 \mathrm{Feb}$. \\
$\mathrm{C} 91$ & 12.67 & 51.21 & $3-5 \mathrm{Feb}$. \\
$\mathrm{C} 98$ & 12.67 & 51.21 & $5-6 \mathrm{Feb}$. \\
$\mathrm{C} 99$ & 12.67 & 51.21 & $6-8 \mathrm{Feb}$. \\
$\mathrm{C} 114$ & 12.67 & 51.21 & $8-11 \mathrm{Feb}$. \\
$\mathrm{C} 128$ & 12.67 & 51.21 & $12-13 \mathrm{Feb}$. \\
$\mathrm{C} 136$ & 12.67 & 51.21 & $14-15 \mathrm{Feb}$. \\
$\mathrm{C} 140$ & 12.67 & 51.21 & $16-17 \mathrm{Feb}$. \\
\hline
\end{tabular}

and reconstructed with $2.5 \% \mathrm{HNO}_{3} / 0.01 \% \mathrm{HF}$. The average chemical recovery of the analytical process was $94 \pm 4 \%(n=173)$, and the uncertainty of the ${ }^{230} \mathrm{Th} /{ }^{229} \mathrm{Th}$ ratios averaged $1.5 \pm 0.6 \%(n=173)$. The activity of ${ }^{238} \mathrm{U}$ was derived from salinity using the relationship given by Owens et al. (2011). The ${ }^{234}$ Th activity uncertainties were calculated by propagating uncertainties associated with counting, detector background and calibration, ICP-MS measurements and ${ }^{238} \mathrm{U}$ activities, and were always $<10 \%$ (average: $8.9 \pm 0.3 \%, n=173$ ). All data of total ${ }^{234} \mathrm{Th}$ and ${ }^{238} \mathrm{U}$ activities are available at http://dx.doi.org/10.1594/PANGAEA.848823.

\section{3. ${ }^{234} \mathrm{Th}, \mathrm{POC}$ and $\mathrm{PON}$ in particles}

Sinking particles were collected using surface-tethered sediment traps deployed for 1-3 days (Table 2). The sediment traps (ST) were attached to a drifting array with a surface buoy equipped with a GPS satellite transmitter, two surface floats and 12 buoyancy balls acting as wave breakers in order to reduce the hydrodynamic stress on traps. The ST array was equipped with two sets of four gimbal mounted collection cylinders positioned at nominal depths of 100-120 m and 300-320 m, respectively. At each depth, three cylinders were filled with an unpoisoned brine solution for biogeochemical analyses and one cylinder with a viscous gel to preserve sinking particles in their original shape. This type of array was deployed a total of 11 times, including 7 deployments at the central station (C91, C98, C99, C114, C128, C136, C140) between 3 and 17 February. One of the cylinders for biogeochemical analyses was used after picking off swimmers under a binocular microscope: (i) one half was filtered through a pre-combusted QMA filter to analyse ${ }^{234} \mathrm{Th}, \mathrm{POC}$ and PON on the same filter as recommended by Buesseler et al. (2006); and (ii) the other half split was filtered using a pre-combusted GF/F filter to analyse POC and PON. The total POC and PON fluxes collected with the ST were determined as the average of the fluxes obtained from samples (i) and (ii). Additionally, four Challenger in-situ pumps (ISP) were deployed at 100, 150, 300 and $400 \mathrm{~m}$ at two stations (C91 and 139) to collect particles using $53-\mu \mathrm{m}$ pore size nylon mesh screens (Table 2). Particles were subsequently rinsed with filtered seawater and re-filtered through a pre-combusted QMA filter to analyse ${ }^{234} \mathrm{Th}$, POC and PON after removing swimmers from the filters. The activity of ${ }^{234} \mathrm{Th}$ in particles was first measured on board and re-measured at the home laboratory 10 months later as described for the water samples. POC and PON were determined with an EuroVector Elemental Analyser, pre-treating the filters with diluted $\mathrm{HCl}$ (Knap et al., 1996). The samples were corrected for POC and PON blanks (1.38 and $0.20 \mu \mathrm{mol}$, respectively), which

Table 2

Sampling of particles using sediment traps and in-situ pumps: location, depth, date, duration of the deployment (sediment traps) and filtered volume (in-situ pumps).

\begin{tabular}{|c|c|c|c|c|c|c|}
\hline \multirow[t]{2}{*}{ Station } & \multicolumn{3}{|c|}{ Deployment sediment traps } & \multicolumn{3}{|c|}{ Deployment in-situ pumps } \\
\hline & Depth $(\mathrm{m})$ & Date (2012) & Duration (h) & Depth (m) & Date (2012) & Volume (L) \\
\hline 86 & 100,300 & 29 Jan. & 23 & & & \\
\hline 87 & 100,300 & 2 Feb. & 20 & & & \\
\hline 137 & 120,320 & 14 Feb. & 15 & & & \\
\hline 139 & 120,320 & 15 Feb. & 19 & $100,150,300,400$ & 16 Feb. & $250-900$ \\
\hline C91 & 100,300 & 3 Feb. & 53 & $100,150,300,400$ & 3 Feb. & $450-1200$ \\
\hline C98 & 100,300 & 5 Feb. & 18 & & & \\
\hline C99 & 100,300 & 6 Feb. & 50 & & & \\
\hline C114 & 100,300 & 8 Feb. & 72 & & & \\
\hline C128 & 120,320 & 12 Feb. & 29 & & & \\
\hline C136 & 120,320 & 14 Feb. & 22 & & & \\
\hline C140 & 120,320 & 16 Feb. & 18 & & & \\
\hline
\end{tabular}


on average represented about $2 \%$ of the POC and PON measurements.

\subsection{Pigments in sediment traps}

One-fifth of a ST cylinder dedicated to biogeochemical analyses was used to analyse pigments after picking off swimmers. Diluted ST samples were filtered through GF/F filters, under low-vacuum pressure (below $20 \mathrm{kPa}$ ). Filtered samples were then immediately shock-frozen in liquid nitrogen and stored at $-80{ }^{\circ} \mathrm{C}$ until further analyses by high performance liquid chromatography (HPLC) at the Alfred Wegener Institute in Bremerhaven, Germany. Pigments from ST samples were analysed based on the HPLC method of Barlow et al. (1997) as detailed in Cheah et al. (2017). The samples were measured using a Waters 600 (Waters, USA) controller combined with a Waters 2998 photodiode array detector, and a Water 717plus auto sampler. $100 \mu \mathrm{L}$ of canthaxanthin was added to each sample as internal standard. Pigments were identified and quantified using the EMPOWER software provided by Waters. Three pigment-based phytoplankton size classes (micro-, nano-, and picophytoplankton) were estimated following the method of Uitz et al. (2009), which has been tested for the Southern Ocean waters. Microphytoplankton corresponded to phytoplankton with size $>20 \mu \mathrm{m}$, nanophytoplankton between 2 and $20 \mu \mathrm{m}$, and picophytoplankton between 0.2 and $2 \mu \mathrm{m}$.

\subsection{Chl-a and POC in the water column}

Seawater samples for Chl-a (Chl- $\left.a_{\mathrm{SW}}\right)$ and POC determination were obtained from Niskin bottles attached to the CTD rosette from 5 to 6 depths in the upper $100 \mathrm{~m}$ at 33 stations. For Chl- $a_{\mathrm{SW}}$ analysis, samples were filtered onto GF/F filters at pressure below $20 \mathrm{kPa}$. Filters were immediately transferred to centrifuge tubes with $10 \mathrm{ml} \mathrm{90 \%} \mathrm{acetone} \mathrm{and} 1 \mathrm{~cm}^{3}$ of glass beads. The tubes were sealed and stored at $-20^{\circ} \mathrm{C}$ for at least $30 \mathrm{~min}$. Chl-a was extracted by placing the centrifuge tubes in a grinder for $3 \mathrm{~min}$ followed by centrifugation at $0{ }^{\circ} \mathrm{C}$. The supernatant was poured in quartz tubes and measured for Chl-a content in a Turner 10-AU fluorometer. The fluorometer was calibrated at the beginning and at the end of the expedition. Chl-a content was calculated using the equation given in Knap et al. (1996) using average parameter values from both calibrations. For POC analysis, samples were filtered onto pre-combusted GF/F filters at pressure not exceeding $20 \mathrm{kPa}$. Filters were immediately transferred to pre-combusted glass Petri dishes and dried overnight at $50{ }^{\circ} \mathrm{C}$. Dried filters were stored at $-20^{\circ} \mathrm{C}$ until analysis at the home laboratory using an EuroVector Elemental Analyser. The samples were corrected for POC blanks and the uncertainty of the POC measurements was $1.9 \%$ based on three reference standards.

\subsection{Satellite Chl-a concentration}

Satellite Chl-a concentrations were taken from the merged daily OC-CCI Chl-a data (ESACCI-OC-L3S product, $\sim 4 \mathrm{~km}$, version2, http://www.oceancolour.org) and averaged over the time period of the study sampling. The OC-CCI data product combines the Medium Resolution Imaging Spectrometer (MERIS) on the Envisat satellite, the Moderate Resolution Imaging Spectrometer (MODIS) on the Aqua satellite and the Sea-viewing Wide Field-of-view Sensor (SeaWiFS) on the OrbView-2 satellite to one Chl-a product. This data product improves coverage of satellite Chl-a data in polar regions by a factor of two to three as compared to using the products of one single sensor. More details on the processing steps can be found in the product user guide (OC-CCI, 2015).

\section{Results}

\subsection{Study area}

Detailed hydrographic information can be found in Strass et al. (2017) and Leach et al. (2017). The study area was placed between the APF and the SPF within the ACC and around a central station located at $51.21^{\circ} \mathrm{S} 12.67^{\circ} \mathrm{W}$. The main water masses identified were: Winter Water (WW, minimum potential temperature, $\left.\theta_{\text {min }}=1.1-1.9^{\circ} \mathrm{C}, 100-200 \mathrm{~m}\right)$, Upper Circumpolar Deep Water (UCDW, $\theta_{\max }=2.1-2.4^{\circ} \mathrm{C}, 400-500 \mathrm{~m}$ ) and Antarctic Bottom Water (AABW, $\theta_{\min } \sim-0.2^{\circ} \mathrm{C}$ ). The mixed layer depth (MLD) varied from 24 to $98 \mathrm{~m}$ (average: $67 \pm 18 \mathrm{~m}, n=73$, Strass et al., 2017). At the central station the structure of the upper water column varied over time: (i) the MLD ranged from $\sim 75$ to $100 \mathrm{~m}$, and some profiles did not show a homogeneous surface layer; (ii) the location of the WW $\theta_{\text {min }}$ fluctuated several tens of metres above and below $150 \mathrm{~m}$; (iii) many profiles showed temperature inversions below the $\theta_{\text {min }}$ depth and fluctuations of salinity and density within the depth range $200-300 \mathrm{~m}$ during the second half of the sampling period. Moreover, at the central station currents flowing to the NE were intensified over time with speeds averaging from 2 to $10 \mathrm{~cm} \mathrm{~s}^{-1}$ for the top $500 \mathrm{~m}$ (Strass et al., 2017).

Satellite-derived Chl-a concentrations during the sampling period were, on average, lower than $1.5 \mathrm{mg} \mathrm{m}^{-3}$ (Fig. 1), whereas at the peak of the bloom, during the first half of January, the Chl-a concentrations were $\sim 3 \mathrm{mg} \mathrm{m}^{-3}$ (Hoppe et al., 2017). The euphotic zone depth ranged between 36 and $66 \mathrm{~m}$ (average: $45 \pm 7 \mathrm{~m}, n=40$, Cheah et al., 2017). Nutrient concentrations and deficits are described in Hoppe et al. (2017). On average, macronutrient concentrations within the euphotic zone were $\sim 21 \mathrm{mmol}$ $\mathrm{NO}_{3} \mathrm{~m}^{-3}, \sim 1.4 \mathrm{mmol} \mathrm{PO}_{4} \mathrm{~m}^{-3}$ and $\sim 6.6 \mathrm{mmol} \mathrm{Si}(\mathrm{OH})_{4} \mathrm{~m}^{-3}$. High iron concentrations that allowed the development of the massive bloom likely reached the study site via advection through the ACC (L.M. Laglera, pers. comm.). Concentrations of dissolved iron $(<0.2 \mu \mathrm{m}$ ) were on average $0.12 \pm 0.03 \mathrm{nM}$ within the top $100 \mathrm{~m}$ of the water column (Hoppe et al., 2017), suggesting that dissolved iron was already depleted by phytoplankton activity during our sampling.

\section{2. ${ }^{234}$ Th activity profiles and fluxes}

The vertical profiles of ${ }^{234} \mathrm{Th}$ and ${ }^{238} \mathrm{U}$ activity in the water column are shown in Fig. 2. Significant deficits of ${ }^{234} \mathrm{Th}$ with respect to ${ }^{238} \mathrm{U}$ were present in surface waters down to $100-170 \mathrm{~m}$ at all stations, with ${ }^{234} \mathrm{Th} /{ }^{238} \mathrm{U}$ ratios averaging $0.67 \pm 0.11$ throughout the upper $100 \mathrm{~m}$. In most cases, the base of these deficits matched well with the base of the primary production zone (PPZ, Fig. 2), defined as the depth at which fluorescence reaches $10 \%$ of its maximum value (Owens, 2013). The PPZ extended, on average, down to $117 \pm 12 \mathrm{~m}$, and the NPP at $100 \mathrm{~m}$ (deepest depth for NPP determination) ranged from 0.09 to $0.44 \mathrm{mmol} \mathrm{C} \mathrm{m} \mathrm{C}^{-3} \mathrm{~d}^{-1}$, confirming that primary production was occurring at least until $100 \mathrm{~m}$ (C. Hoppe, pers. comm.). Below the $\mathrm{PPZ}$, significant excesses of ${ }^{234} \mathrm{Th}\left({ }^{234} \mathrm{Th} /{ }^{238} \mathrm{U}\right.$ ratio $\left.>1.1\right)$ were detected at stations C91 and 106 at one single depth $(500 \mathrm{~m})$. Significant ${ }^{234} \mathrm{Th}$ deficits $\left({ }^{234} \mathrm{Th} /{ }^{238} \mathrm{U}\right.$ ratio $\left.<0.9\right)$ below the PPZ were also found at single depths at stations 93, C128, 137 and 139 (150, 750, 500 and $400 \mathrm{~m}$, respectively). The central station showed a larger ${ }^{234} \mathrm{Th}$ deficit along the top $100 \mathrm{~m}$ during the second and third visits (C128 and C140: $(90 \pm 6) \cdot 10^{3}$ and $(86 \pm 6) \cdot 10^{3} \mathrm{dpm} \mathrm{m}^{-2}$, respectively) compared to the first sampling (C91: $\left.(71 \pm 6) \cdot 10^{3} \mathrm{dpm} \mathrm{m}^{-2}\right)$.

${ }^{234} \mathrm{Th}$ fluxes $\left(F_{\mathrm{Th}}\right.$, in $\left.\mathrm{dpm} \mathrm{m} \mathrm{m}^{-2} \mathrm{~d}^{-1}\right)$ are attributed to scavenging of ${ }^{234} \mathrm{Th}$ onto particles sinking out of surface waters. Here, we estimated these fluxes using two methods: (i) from seawater 


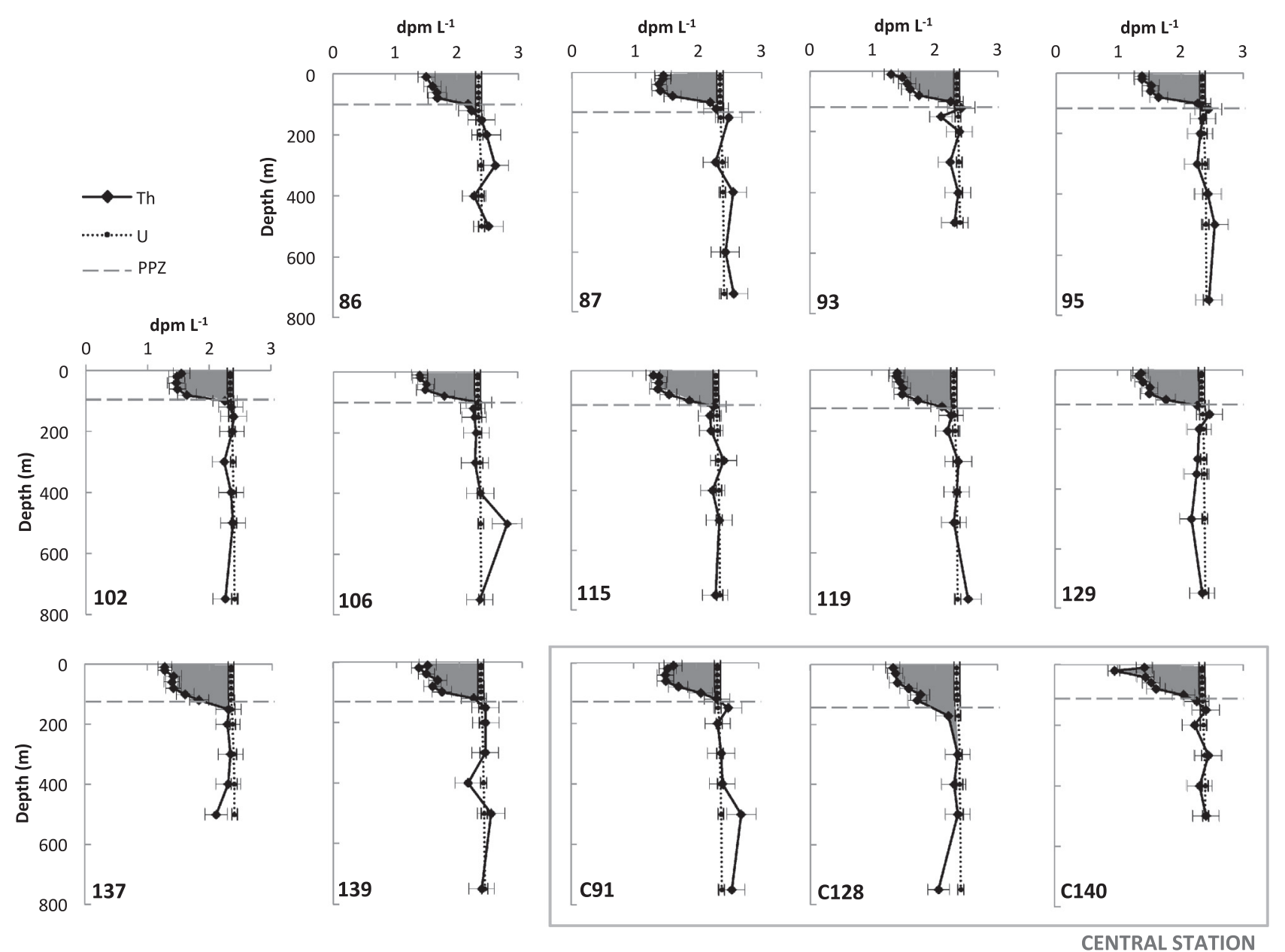

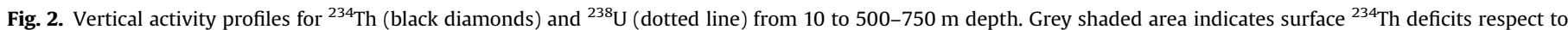

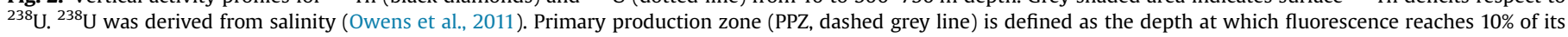
maximum value (Owens, 2013).

samples $\left(F_{\mathrm{Th}, \mathrm{SW}}\right)$, and (ii) directly from sediment traps $\left(F_{\mathrm{Th}, \mathrm{ST}}\right)$. The $F_{\mathrm{Th}, \mathrm{SW}}$ were calculated using a steady state (SS) model, neglecting advective and diffusive fluxes (Buesseler et al., 1992):

$F_{\mathrm{Th}}=\lambda_{\mathrm{Th}}\left(A_{\mathrm{U}}-A_{\mathrm{Th}}\right)$

where $\lambda_{\mathrm{Th}}$ is the decay constant of ${ }^{234} \mathrm{Th}\left(0.029 \mathrm{~d}^{-1}\right)$ and $\left(A_{\mathrm{U}}-A_{\mathrm{Th}}\right)$ is the integrated ${ }^{234} \mathrm{Th}$ deficit in the upper water column $\left(\mathrm{dpm} \mathrm{m} \mathrm{m}^{-2}\right)$. We obtained the integrated ${ }^{234} \mathrm{Th}$ deficit with rectangular integration for two different horizon depths (100 and $300 \mathrm{~m}$ ), allowing comparison with the ${ }^{234} \mathrm{Th}$ fluxes obtained directly from ST (Table 3 ).

Additionally, since the central station was sampled several times and the activity of ${ }^{234} \mathrm{Th}$ may have changed over time as a consequence of the sinking of the phytoplankton bloom (e.g. Savoye et al., 2006), ${ }^{234}$ Th fluxes were also calculated using a nonsteady state (NSS) model at 100 and $300 \mathrm{~m}$ (Table 4). This model assumes that the same water masses are sampled at all visits and ignores advective and diffusive fluxes of ${ }^{234} \mathrm{Th}$ (Savoye et al., 2006):

$F_{\mathrm{Th}}=\lambda_{\mathrm{Th}}\left[\frac{A_{U}\left(1-e^{-\lambda \Delta t}\right)+A_{\mathrm{Th} 1} \mathrm{e}^{-\lambda \Delta t}-A_{\mathrm{Th} 2}}{1-e^{-\lambda \Delta t}}\right]$

where $A_{U}$ is the activity of ${ }^{238} \mathrm{U}, \Delta t$ is the time interval between two visits of a single station and $A_{\mathrm{Th} 1}$ and $A_{\mathrm{Th} 2}$ are the activities of ${ }^{234} \mathrm{Th}$ at the first and second visits, respectively.

$F_{\mathrm{Th}, \mathrm{SW}}$ and $F_{\mathrm{Th}, \mathrm{ST}}$ estimates at 100 and $300 \mathrm{~m}$ are presented in Tables 3 and 4 and Fig. 3. Though some traps were placed $20 \mathrm{~m}$ deeper than the seawater sampling, we will still use 100 and $300 \mathrm{~m}$ to refer to 100 or $120 \mathrm{~m}$ and 300 or $320 \mathrm{~m}$, respectively.

The SS estimates of $F_{\mathrm{Th}, \mathrm{SW}}$ at $100 \mathrm{~m}$ were relatively homogeneous over the entire study area and not significantly different from those at the base of the ${ }^{234} \mathrm{Th}$ deficit ( $\sim 120 \mathrm{~m}$, Wilcoxon test, $\left.p>0.05\right)$, ranging from $1960 \pm 210$ to $3100 \pm 180 \mathrm{dpm} \mathrm{m}^{-2} \mathrm{~d}^{-1}$ (average: $\left.2390 \pm 340 \mathrm{dpm} \mathrm{m} \mathrm{m}^{-2} \mathrm{~d}^{-1}, n=14\right)$. Fluxes at $300 \mathrm{~m}$ had greater uncertainties than those at $100 \mathrm{~m}$, and ranged from $1490 \pm 710$ to $3870 \pm 700 \mathrm{dpm} \mathrm{m}^{-2} \mathrm{~d}^{-1}$ (average: $2650 \pm 610 \mathrm{dpm} \mathrm{m}^{-2} \mathrm{~d}^{-1}$, $n=14)$. The $F_{\mathrm{Th}, \mathrm{SW}}$ over the study area showed no significant differences between 100 and $300 \mathrm{~m}$ (t-test, $p>0.05$ ) (Fig. 3). Focusing on the central station, $F_{\mathrm{Th}, \mathrm{sw}}$ increased from C91 to C128 at both 100 and $300 \mathrm{~m}$ depth, reaching $\sim 3000$ and $4000 \mathrm{dpm} \mathrm{m}^{-2} \mathrm{~d}^{-1}$, respectively. The $F_{\mathrm{Th}, \mathrm{SW}}$ at station $\mathrm{C} 140$ were not significantly different from those at station C128 (Table 3). According to the NSS model, the $F_{\mathrm{Th}, \mathrm{Sw}}$ decreased substantially from C91-C128 to C128C140, especially at $300 \mathrm{~m}$ (Table 4).

$F_{\mathrm{Th}, \mathrm{ST}}$ at $100 \mathrm{~m}$ ranged from $1050 \pm 90$ to $4000 \pm$ $320 \mathrm{dpm} \mathrm{m}^{-2} \mathrm{~d}^{-1}$ (average: $1720 \pm 890 \mathrm{dpm} \mathrm{m}^{-2} \mathrm{~d}^{-1}, \quad n=10$ ) (Table 3). A flux reduction of about $40 \%$ between 100 and $300 \mathrm{~m}$ was found at most stations, except at C128 and C140, where no significant differences were observed. At the central station, $F_{\mathrm{Th}, \mathrm{ST}}$ at $100 \mathrm{~m}$ were relatively constant from C91 to C140, with an average of $1330 \pm 170 \mathrm{dpm} \mathrm{m}^{-2} \mathrm{~d}^{-1}(n=6) . F_{\mathrm{Th}, \mathrm{ST}}$ at $300 \mathrm{~m}$ were also similar during the entire sampling time, averaging $900 \pm 200 \mathrm{dpm} \mathrm{m}^{-2} \mathrm{~d}^{-1}(n=6)$. 
Table 3

${ }^{234} \mathrm{Th}$ export fluxes derived from seawater $\left(F_{\mathrm{Th}, \mathrm{SW}}\right)$ assuming steady state conditions, together with the fluxes derived directly from the sediment traps $\left(F_{\mathrm{Th}, \mathrm{ST}}\right)$ at different depths.

\begin{tabular}{|c|c|c|c|}
\hline Station & Depth $(\mathrm{m})$ & 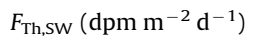 & $F_{\mathrm{Th}, \mathrm{ST}}\left(\mathrm{dpm} \mathrm{m} \mathrm{m}^{-2} \mathrm{~d}^{-1}\right)$ \\
\hline \multirow[t]{2}{*}{86} & 100 & $1960 \pm 210$ & $1700 \pm 140$ \\
\hline & 300 & $1490 \pm 710$ & $970 \pm 80$ \\
\hline \multirow[t]{2}{*}{87} & 100 & $2360 \pm 170$ & $4000 \pm 320$ \\
\hline & 300 & $2350 \pm 710$ & $1990 \pm 170$ \\
\hline \multirow[t]{2}{*}{93} & 100 & $2080 \pm 180$ & \\
\hline & 300 & $2530 \pm 630$ & \\
\hline \multirow[t]{2}{*}{95} & 100 & $2220 \pm 180$ & \\
\hline & 300 & $2510 \pm 620$ & \\
\hline \multirow[t]{2}{*}{102} & 100 & $2150 \pm 180$ & \\
\hline & 300 & $2360 \pm 640$ & \\
\hline \multirow[t]{2}{*}{106} & 100 & $2090 \pm 190$ & \\
\hline & 300 & $2440 \pm 660$ & \\
\hline \multirow[t]{2}{*}{115} & 100 & $2480 \pm 170$ & \\
\hline & 300 & $2860 \pm 470$ & \\
\hline \multirow[t]{2}{*}{119} & 100 & $2440 \pm 170$ & \\
\hline & 300 & $3020 \pm 640$ & \\
\hline \multirow[t]{2}{*}{129} & 100 & $2520 \pm 170$ & \\
\hline & 300 & $2910 \pm 520$ & \\
\hline \multirow[t]{2}{*}{137} & 120 & $3100 \pm 180$ & $1090 \pm 100$ \\
\hline & $300-320$ & $3620 \pm 620$ & $620 \pm 60$ \\
\hline \multirow[t]{4}{*}{139} & 120 & $2510 \pm 200$ & $2440 \pm 200$ \\
\hline & 150 & $2540 \pm 260$ & \\
\hline & $300-320$ & $2340 \pm 660$ & $1870 \pm 160$ \\
\hline & 400 & $2660 \pm 900$ & \\
\hline \multirow[t]{4}{*}{ C91 } & 100 & $2050 \pm 180$ & $1470 \pm 120$ \\
\hline & 150 & $2070 \pm 270$ & \\
\hline & 300 & $1980 \pm 660$ & $900 \pm 70$ \\
\hline & 400 & $1910 \pm 910$ & \\
\hline \multirow[t]{2}{*}{ C98 } & 100 & & $1430 \pm 120$ \\
\hline & 300 & & $790 \pm 70$ \\
\hline \multirow[t]{2}{*}{ C99 } & 100 & & $1370 \pm 110$ \\
\hline & 300 & & $960 \pm 80$ \\
\hline \multirow[t]{2}{*}{ C114 } & 100 & & $1200 \pm 100$ \\
\hline & 300 & & $590 \pm 50$ \\
\hline \multirow[t]{2}{*}{$\mathrm{C} 128$} & 120 & $2950 \pm 200$ & $1050 \pm 90$ \\
\hline & $300-320$ & $3870 \pm 700$ & $920 \pm 80$ \\
\hline \multirow[t]{2}{*}{ C140 } & 120 & $2600 \pm 210$ & $1450 \pm 130$ \\
\hline & $300-320$ & $2800 \pm 650$ & $1220 \pm 110$ \\
\hline
\end{tabular}

\section{Table 4}

${ }^{234} \mathrm{Th}$ export fluxes derived from seawater $\left(F_{\mathrm{Th}, \mathrm{SW}}\right)$ at 100 and $300 \mathrm{~m}$ at the central station assuming non-steady state conditions. $t_{2}-t_{1}$ is the time interval between two occupations of the central station.

\begin{tabular}{lccc}
\hline Stations & $t_{2}-t_{1}$ (days) & Depth $(\mathrm{m})$ & $F_{\mathrm{Th}, \mathrm{SW}}\left(\mathrm{dpm} \mathrm{m} \mathrm{m}^{-2} \mathrm{~d}^{-1}\right)$ \\
\hline C91-C128 & 10 & 100 & $4290 \pm 880$ \\
& & 300 & $9600 \pm 3400$ \\
C128-C140 & 4 & 100 & $1600 \pm 2000$ \\
& & 300 & $-5500 \pm 7600$ \\
\hline
\end{tabular}

Globally, the ${ }^{234} \mathrm{Th}$ fluxes estimated using the SS approach and ST were comparable at $100 \mathrm{~m}$ (Wilcoxon test, $p>0.05, F_{\mathrm{Th}, \mathrm{SW}} / F_{\mathrm{Th}}$ $\mathrm{sT}=1.7 \pm 0.9, n=7)$, whereas at $300 \mathrm{~m}$ the $F_{\mathrm{Th}, \mathrm{SW}}$ were higher than the $F_{\mathrm{Th}, \mathrm{ST}}$ estimates by an average factor of $2.6 \pm 1.7(n=7)$.
3.2.1. Impact of physical transport processes on the $F_{T h, S W}$ estimates The physical transport processes can be parameterised as (e.g. Savoye et al., 2006):

$V= \pm u \frac{\partial A_{\mathrm{Th}}}{\partial x} \pm v \frac{\partial A_{\mathrm{Th}}}{\partial y} \pm w \frac{\partial A_{\mathrm{Th}}}{\partial z} \pm K_{x} \frac{\partial^{2} A_{\mathrm{Th}}}{\partial x^{2}} \pm K_{y} \frac{\partial^{2} A_{\mathrm{Th}}}{\partial y^{2}} \pm K_{z} \frac{\partial^{2} A_{\mathrm{Th}}}{\partial z^{2}}$

where advective and diffusive components are included along the $x, y$ and $z$ directions. Velocities are denoted by $u, v$ and $w, \frac{\partial A_{\mathrm{Th}}}{\partial x}, \frac{\partial A_{\mathrm{Th}}}{\partial y}$ and $\frac{\partial A_{\mathrm{Th}}}{\partial z}$ are the ${ }^{234} \mathrm{Th}$ activity gradients and $K_{x}, K_{y}$ and $K_{z}$ are the diffusion coefficients. Vertical advection needs to be considered in areas of established upwelling, while horizontal advection should be taken into account in ocean margins, where this process likely plays a relevant role (Savoye et al., 2006). During our survey the vertical advection was presumably negligible, while horizontal advection was significant with mean currents of about $7 \mathrm{~cm} \mathrm{~s}^{-1}$ for the top 100 and $300 \mathrm{~m}$ (V. Strass, pers. comm.). Buesseler et al. (1994) showed that advection is dominant over diffusion in the horizontal transport of ${ }^{234} \mathrm{Th}$ in open waters. Therefore, we focused our attention on the horizontal advection in order to have a first estimate of the importance of the physical transport in the present study or, in other words, to test the accuracy of our ${ }^{234} \mathrm{Th}$ export estimates. We addressed this issue considering: (i) the mean $u$ and $v$ velocities over the area $50.67-51.67^{\circ} \mathrm{S}$ and $11.92-13.50^{\circ} \mathrm{W}$ for the top 100 and $300 \mathrm{~m}: u=5.6 \mathrm{~cm} \mathrm{~s}^{-1}, \quad v=4.3 \mathrm{~cm} \mathrm{~s}^{-1}$ and $u=5.7 \mathrm{~cm} \mathrm{~s}^{-1}, v=3.9 \mathrm{~cm} \mathrm{~s}^{-1}$, respectively (V. Strass, pers. comm.); (ii) the ${ }^{234} \mathrm{Th}$ activity gradients for the top 100 and $300 \mathrm{~m}$ (excluding station 86): $\frac{\partial A_{\mathrm{Th}}}{\partial x}=(6.3 \pm 7.9) \cdot 10^{-2} \mathrm{dpm} \mathrm{m}^{-3}, \frac{\partial A_{\mathrm{Th}}}{\partial y}=$ $(7.4 \pm 6.1) \cdot 10^{-2} \mathrm{dpm} \mathrm{m}^{-3}$ and $\frac{\partial A_{\mathrm{Th}}}{\partial x}=(2.4 \pm 3.0) \cdot 10^{-1} \mathrm{dpm} \mathrm{m}^{-3}$, $\frac{\partial A_{\mathrm{Th}}}{\partial y}=(0.9 \pm 2.2) \cdot 10^{-1} \mathrm{dpm} \mathrm{m} \mathrm{m}^{-3}$, respectively. In this way, the negligence of horizontal advection would lead to an error on the $F_{\mathrm{Th}, \mathrm{SW}}$ estimates of $580 \pm 440 \mathrm{dpm} \mathrm{m}^{-2} \mathrm{~d}^{-1}$ at $100 \mathrm{~m}$ and $1500 \pm 1700 \mathrm{dpm} \mathrm{m}^{-2} \mathrm{~d}^{-1}$ at $300 \mathrm{~m}$. Thus, the physical processes would have a smaller impact on the $F_{\mathrm{Th}, \mathrm{SW}}$ estimates at $100 \mathrm{~m}$ ( $\sim 25 \%)$ than at $300 \mathrm{~m}(\sim 50 \%)$ at the investigated stations due to the smaller spatial variability of ${ }^{234} \mathrm{Th}$ activities in the upper $100 \mathrm{~m}$.

Additionally, we have tested the influence of vertical diffusivity on ${ }^{234} \mathrm{Th}$ export using an intermediate $K_{z}$ value of $10^{-4} \mathrm{~m}^{2} \mathrm{~s}^{-1}$ at $100 \mathrm{~m}$ (Strass et al., 2017; Leach et al., 2017), obtaining a maximum contribution of this process of $30-180 \mathrm{dpm} \mathrm{m}^{-2} \mathrm{~d}^{-1}$. Thus, the contribution of the vertical diffusivity to the $F_{\mathrm{Th}, \mathrm{SW}}$ estimates at $100 \mathrm{~m}$ must have been very small, generally lower than the uncertainties associated with the estimates. It was not possible to reproduce this exercise at $300 \mathrm{~m}$ due to the low ${ }^{234} \mathrm{Th}$ resolution around that depth.

\subsubsection{SS vs. NSS models at the central station}

At the central station we determined the ${ }^{234} \mathrm{Th}$ export with both SS and NSS models. However, changes in the upper water column properties occurred during the sampling period, especially evident when station C128 was occupied (see Section 3.1 and Strass et al., 2017), indicating that different water masses with particular scavenging histories were likely sampled. Furthermore, we have quantified an appreciable impact of advection on the $F_{\mathrm{Th}}$, sw estimates, especially at $300 \mathrm{~m}$ (see Section 3.2.1). This has led us to discard the use of the NSS approach since it can produce large errors when spatial variability is misinterpreted as temporal variability, improving ${ }^{234} \mathrm{Th}$ export estimates only if sampling is conducted in a Lagrangian framework (Resplandy et al., 2012). Additionally, the results obtained from the NSS model (Table 4) are not consistent with results from the ST, which tend to be more constant. Thus, we consider that the SS model gives the best estimate of ${ }^{234} \mathrm{Th}$ export in this study. 


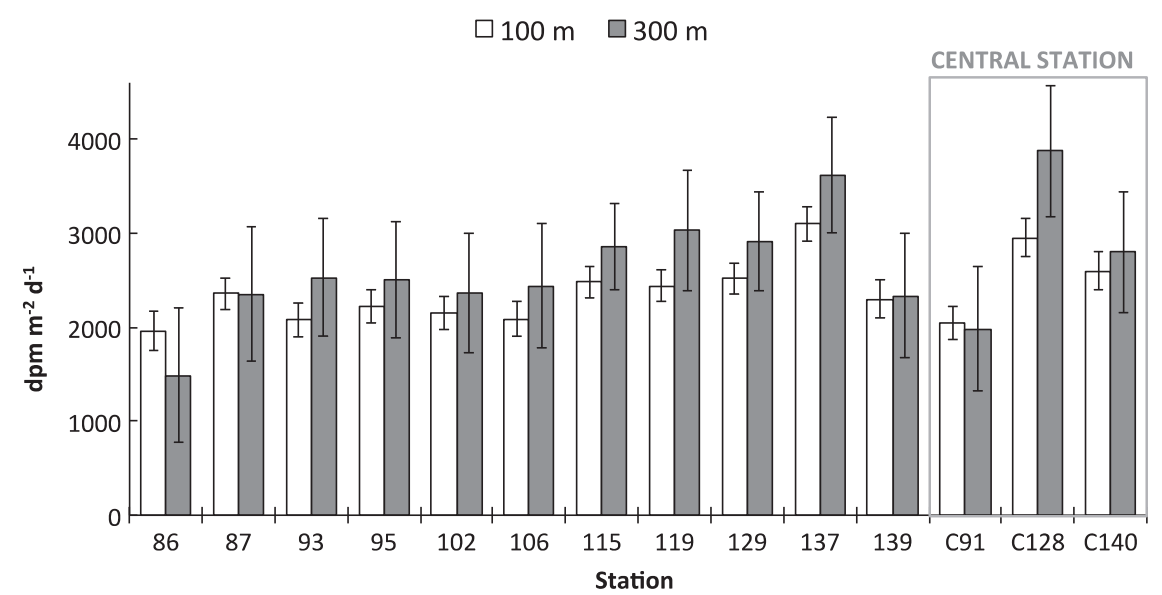

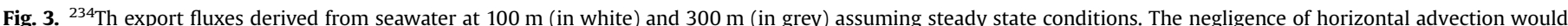

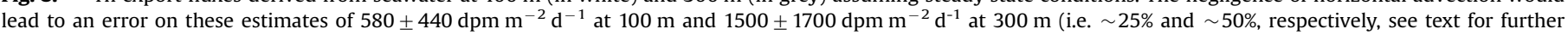
details).

\section{3. $\mathrm{POC} /{ }^{234} \mathrm{Th}$ and $\mathrm{PON} /{ }^{234} \mathrm{Th}$ ratios in particles}

$\mathrm{POC} /{ }^{234} \mathrm{Th}$ and $\mathrm{PON} /{ }^{234} \mathrm{Th}(\mathrm{C} / \mathrm{Th}$ and $\mathrm{N} / \mathrm{Th})$ ratios in particles from ST $\left(\mathrm{C} / \mathrm{Th}_{\mathrm{ST}}\right.$ and $\left.\mathrm{N} / \mathrm{Th}_{\mathrm{ST}}\right)$ and in particles $>53 \mu \mathrm{m}$ collected using ISP (C/Th $\mathrm{TSP}_{\text {IS }}$ and $\left./ \mathrm{Th}_{\mathrm{ISP}}\right)$, usually considered to be sinking particles (e.g. Buesseler et al., 2006), are presented in Table 5.
$\mathrm{C} / \mathrm{Th}_{\mathrm{ST}}$ and $\mathrm{N} / \mathrm{Th}_{\mathrm{ST}}$ ratios at $100 \mathrm{~m}$ averaged $14 \pm 3$ and $1.7 \pm 0.4 \mu \mathrm{mol} \mathrm{dpm}{ }^{-1}(n=10)$, respectively, and were about $30 \%$ lower at $300 \mathrm{~m}$ depth $\left(10 \pm 3\right.$ and $1.1 \pm 0.3 \mu \mathrm{mol} \mathrm{dpm}^{-1}, n=9$, respectively). $\mathrm{C} / \mathrm{Th}_{\mathrm{ISP}}$ and $\mathrm{N} / \mathrm{Th}_{\mathrm{ISP}}$ ratios also decreased with depth between $100-150$ and $300-400 \mathrm{~m}$, by about $60 \%$. At the central station, $\mathrm{C} / \mathrm{Th}_{\mathrm{ST}}$ and $\mathrm{N} / \mathrm{Th}_{\mathrm{ST}}$ ratios at $100 \mathrm{~m}$ decreased by $30 \%$ from

Table 5

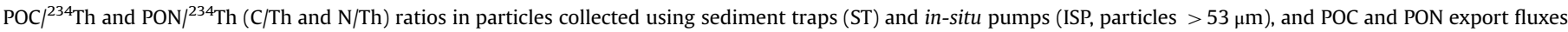
$\left(F_{\mathrm{C}}\right.$ and $\left.F_{\mathrm{N}}\right)$ estimated using the ST, SWST and SWISP methods at different depths (see text for further details)

\begin{tabular}{|c|c|c|c|c|c|c|c|c|c|c|c|}
\hline \multirow[t]{2}{*}{ Station } & \multirow[t]{2}{*}{ Depth (m) } & \multicolumn{2}{|c|}{$\mathrm{C} / \mathrm{Th}\left(\mu \mathrm{mol} \mathrm{dpm}{ }^{-1}\right)$} & \multicolumn{2}{|c|}{$\mathrm{N} / \mathrm{Th}\left(\mu \mathrm{mol} \mathrm{dpm}{ }^{-1}\right)$} & \multicolumn{3}{|c|}{$F_{\mathrm{C}}\left(\mathrm{mmol} \mathrm{m}^{-2} \mathrm{~d}^{-1}\right)$} & \multicolumn{3}{|c|}{$F_{\mathrm{N}}\left(\mathrm{mmol} \mathrm{m}{ }^{-2} \mathrm{~d}^{-1}\right)$} \\
\hline & & ST & ISP $(>53 \mu \mathrm{m})$ & ST & $\operatorname{ISP}(>53 \mu \mathrm{m})$ & ST & SWST & SWISP & ST & SWST & SWISP \\
\hline \multirow[t]{2}{*}{86} & 100 & $10.8 \pm 0.9$ & & $1.4 \pm 0.1$ & & 16 & $21 \pm 3$ & & 2.0 & $2.6 \pm 0.4$ & \\
\hline & 300 & $8.3 \pm 0.7$ & & $0.85 \pm 0.07$ & & 7.3 & $12 \pm 6$ & & 0.74 & $1.3 \pm 0.6$ & \\
\hline \multirow[t]{2}{*}{87} & 100 & $13 \pm 1$ & & $1.5 \pm 0.1$ & & 44 & $31 \pm 3$ & & 5.1 & $3.6 \pm 0.4$ & \\
\hline & 300 & $10.3 \pm 0.9$ & & $1.05 \pm 0.09$ & & 16 & $24 \pm 8$ & & 1.7 & $2.5 \pm 0.8$ & \\
\hline \multirow[t]{2}{*}{137} & 120 & $17 \pm 2$ & & $2.2 \pm 0.2$ & & 15 & $54 \pm 6$ & & 1.8 & $6.7 \pm 0.7$ & \\
\hline & 320 & & & & & ${ }^{\mathrm{a}} 6.3$ & & & & & \\
\hline \multirow[t]{4}{*}{139} & $100-120$ & $10.6 \pm 0.9$ & $29 \pm 2$ & $1.2 \pm 0.1$ & $5.2 \pm 0.4$ & 23 & $26 \pm 3$ & $67 \pm 8$ & 2.5 & $2.9 \pm 0.3$ & $12 \pm 1$ \\
\hline & 150 & & $20 \pm 2$ & & $2.8 \pm 0.3$ & & & $52 \pm 7$ & & & $7 \pm 1$ \\
\hline & $300-320$ & $7.1 \pm 0.6$ & $9.9 \pm 0.9$ & $0.89 \pm 0.07$ & $1.1 \pm 0.1$ & 11 & $17 \pm 5$ & $23 \pm 7$ & 1.3 & $2.1 \pm 0.6$ & $2.6 \pm 0.8$ \\
\hline & 400 & & $9.0 \pm 0.8$ & & $1.3 \pm 0.1$ & & & $24 \pm 8$ & & & $3 \pm 1$ \\
\hline \multirow[t]{4}{*}{ C91 } & 100 & $16 \pm 1$ & $13 \pm 1$ & $1.9 \pm 0.2$ & $2.1 \pm 0.2$ & 17 & $33 \pm 4$ & $26 \pm 3$ & 2.0 & $4.0 \pm 0.5$ & $4.2 \pm 0.5$ \\
\hline & 150 & & $12 \pm 1$ & & $1.7 \pm 0.1$ & & & $25 \pm 4$ & & & $3.5 \pm 0.5$ \\
\hline & 300 & $7.9 \pm 0.6$ & $7.6 \pm 0.6$ & $0.90 \pm 0.07$ & $1.3 \pm 0.1$ & 6.5 & $16 \pm 5$ & $15 \pm 5$ & 0.74 & $1.8 \pm 0.6$ & $2.5 \pm 0.9$ \\
\hline & 400 & & $4.3 \pm 0.3$ & & $0.73 \pm 0.06$ & & & $8 \pm 4$ & & & $1.4 \pm 0.7$ \\
\hline \multirow[t]{2}{*}{ C98 } & 100 & $19 \pm 2$ & & $2.4 \pm 0.2$ & & 25 & & & 3.1 & & \\
\hline & 300 & $17 \pm 2$ & & $1.8 \pm 0.2$ & & 12 & & & 1.2 & & \\
\hline \multirow[t]{2}{*}{ C99 } & 100 & $15 \pm 1$ & & $1.8 \pm 0.1$ & & 16 & & & 2.0 & & \\
\hline & 300 & $9.1 \pm 0.8$ & & $1.06 \pm 0.09$ & & 7.5 & & & 0.88 & & \\
\hline \multirow[t]{2}{*}{ C114 } & 100 & $14 \pm 1$ & & $1.9 \pm 0.2$ & & 16 & & & 2.3 & & \\
\hline & 300 & $9.8 \pm 0.8$ & & $1.3 \pm 0.1$ & & 5.8 & & & 0.77 & & \\
\hline \multirow[t]{2}{*}{ C128 } & 120 & $11 \pm 1$ & & $1.6 \pm 0.1$ & & 13 & $34 \pm 4$ & & 1.7 & $4.6 \pm 0.5$ & \\
\hline & 320 & $12 \pm 1$ & & $1.1 \pm 0.1$ & & 11 & $50 \pm 10$ & & 1.0 & $4.3 \pm 0.9$ & \\
\hline \multirow[t]{2}{*}{ C136 } & 120 & & & & & 11 & & & & & \\
\hline & 320 & & & & & 6.3 & & & & & \\
\hline \multirow[t]{2}{*}{ C140 } & 120 & $11 \pm 1$ & & $1.3 \pm 0.1$ & & 13 & $28 \pm 3$ & & 1.6 & $3.5 \pm 0.4$ & \\
\hline & 320 & $8.6 \pm 0.8$ & & $1.1 \pm 0.1$ & & 8.6 & $24 \pm 6$ & & 1.1 & $3.0 \pm 0.8$ & \\
\hline
\end{tabular}

${ }^{a}$ Calculated from the filter used for POC analysis. The filter used for ${ }^{234} \mathrm{Th}$ and POC analyses has not been considered because it was likely contaminated with organic carbon, presenting an unusually high $\mathrm{C} / \mathrm{N}$ molar ratio (14) compared with the overall sample average $(8 \pm 1)$. 
the beginning until the end of the study, but no significant change was observed at $300 \mathrm{~m}$.

$\mathrm{ST}$ and ISP ratios (C/Th and N/Th) were in reasonable agreement (within a factor of 1.4), except at station 139 at $100 \mathrm{~m}$ depth, where the ISP ratios were about 3-4 times higher than the ST ratios. The molar $\mathrm{C} / \mathrm{N}$ ratio was $8 \pm 1$ for ST ratios $(n=19)$ and $7 \pm 1$ for ISP ratios $(n=8)$.

\subsection{POC and PON fluxes}

We used three methods to estimate POC and PON fluxes $\left(F_{\mathrm{C}}\right.$ and $F_{\mathrm{N}}$, respectively) (Table 5): (i) measured directly with the ST (ST method: $F_{\mathrm{C}, \mathrm{ST}}$ and $F_{\mathrm{N}, \mathrm{ST}}$ ), (ii) combining the $F_{\mathrm{Th}, \mathrm{SW}}$ and the ST ratios (SWST method: $F_{\mathrm{C}, \mathrm{SWST}}$ and $F_{\mathrm{N}, \mathrm{SWST}}$ ), and (iii) combining the $F_{\mathrm{Th}, \mathrm{SW}}$ and the ISP ratios (SWISP method: $F_{\mathrm{C}, \mathrm{SWISP}}$ and $F_{\mathrm{N}, \mathrm{SWISP}}$ ). For (ii) and (iii) we used the SS estimates of $F_{\mathrm{Th}}$ and the C/Th (or N/Th) ratios in sinking particles, as:

$F_{\mathrm{C}}=F_{\mathrm{Th}}(\mathrm{C} / \mathrm{Th})$

The average $F_{\mathrm{C}, \mathrm{ST}}$ and $F_{\mathrm{N}, \mathrm{ST}}$ at $100 \mathrm{~m}$ were $19 \pm 9$ and $2 \pm 1 \mathrm{mmol} \mathrm{m}^{-2} \mathrm{~d}^{-1}(n=11)$, respectively, with maxima at station 87 . $F_{\mathrm{C}, \mathrm{ST}}$ and $F_{\mathrm{N}, \mathrm{ST}}$ at $300 \mathrm{~m}$ averaged $9 \pm 3$ and $1.0 \pm 0.3 \mathrm{mmol} \mathrm{m}^{-2} \mathrm{~d}^{-1}$ $(n=11)$, respectively, about $60 \%$ less than the fluxes at $100 \mathrm{~m}$ except at stations C128, C136 and C140. During the occupation of the central station, $F_{\mathrm{C}, \mathrm{ST}}$ and $F_{\mathrm{N}, \mathrm{ST}}$ at $100 \mathrm{~m}$ decreased by $25 \%$ over the study period, while they increased by $30 \%$ and $50 \%$, respectively, at $300 \mathrm{~m}$.

$F_{\mathrm{C}, \mathrm{SWST}}$ and $F_{\mathrm{N}, \mathrm{SWST}}$ at $100 \mathrm{~m}$ averaged $30 \pm 10$ and $4 \pm 1 \mathrm{mmol} \mathrm{m}^{-2} \mathrm{~d}^{-1}(n=7)$, respectively. Fluxes at $300 \mathrm{~m}$ averaged $20 \pm 10$ and $2 \pm 1 \mathrm{mmol} \mathrm{m}^{-2} \mathrm{~d}^{-1}(n=6)$, respectively, about $40 \%$ less than the fluxes at $100 \mathrm{~m}$ except at stations C128 and C140. $F_{\mathrm{C}, \mathrm{SWST}}$ and $F_{\mathrm{N}, \text { SWST }}$ estimates at the central station showed changes $<5 \%$ with time at $100 \mathrm{~m}$, whereas the fluxes at $300 \mathrm{~m}$ were more variable, with a maximum $F_{\mathrm{C}, \text { SWST }}$ of $50 \pm 10 \mathrm{mmol} \mathrm{m}^{-2} \mathrm{~d}^{-1}$ at C128.

The SWISP method was used at the two stations where ISP were deployed. $F_{\mathrm{C}, \mathrm{SWST}}$ and $F_{\mathrm{N}, \mathrm{SWST}}$ at station 139 were higher than at C91 by a factor of about 2, at both $100-150 \mathrm{~m}$ and $300-400 \mathrm{~m}$. Fluxes at $300 \mathrm{~m}$ were lower than those at $100 \mathrm{~m}$ by $40 \%$ (C91) and 70\% (139).

Overall, the $F_{\mathrm{C}}$ and $F_{\mathrm{N}}$ estimated by using SW samples $\left(F_{\mathrm{C}, \mathrm{SWST}}, F_{\mathrm{N}}\right.$, swst and $\left.F_{\mathrm{C}, \mathrm{SWISP}} F_{\mathrm{N}, \mathrm{SWISP}}\right)$ were greater than those measured with ST by a factor of $2.0 \pm 1.0$ and $2.3 \pm 1.3(n=17)$, respectively, at $100 \mathrm{~m}$, and $2.4 \pm 1.0$ and $2.5 \pm 1.0(n=17)$, respectively, at $300 \mathrm{~m}$.

(A)

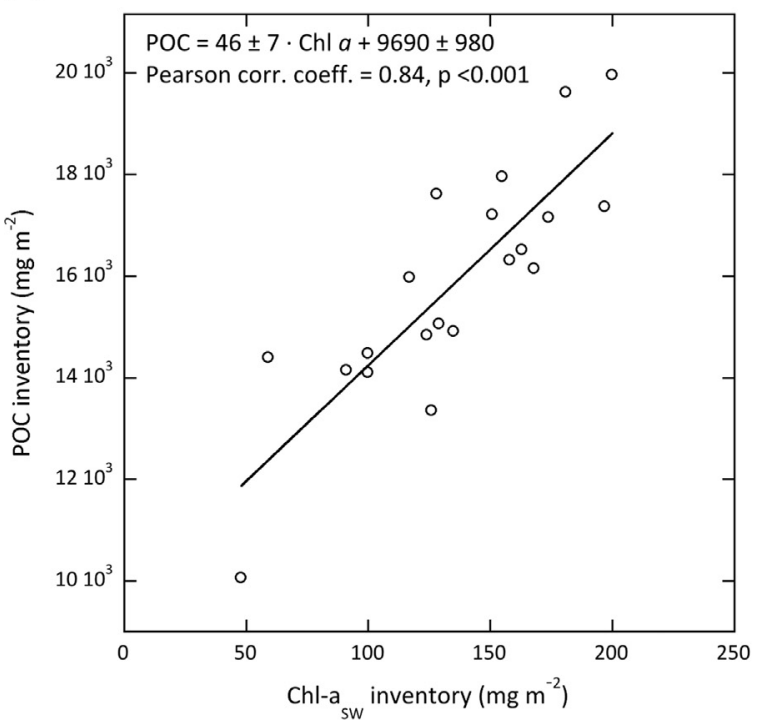

\subsection{Chl-a and POC in the water column}

The Chl- $a_{\mathrm{SW}}$ inventories down to $100 \mathrm{~m}$ were, in most instances, larger than $100 \mathrm{mg} \mathrm{m}^{-2}$ (Fig. 4A), with highest inventories ( $>180 \mathrm{mg} \mathrm{m}^{-2}$ ) at the SE quadrant of the study site, while stations 87 and 139, located to the NW, presented the lowest values $\left(\sim 50 \mathrm{mg} \mathrm{m}^{-2}\right)$. At the central station the Chl- $a_{\mathrm{Sw}}$ inventories ranged from 130 to $200 \mathrm{mg} \mathrm{m}^{-2}$, decreasing by about $30 \%$ from the beginning until the end of sampling, with fluctuations over time. The POC inventories down to $100 \mathrm{~m}$ ranged from $10 \cdot 10^{3}$ to $26 \cdot 10^{3} \mathrm{mg} \mathrm{m}^{-2}$, showing a strong positive correlation with Chl- $a_{\mathrm{SW}}(p<0.001$; Pearson correlation coefficient, $r=0.84 ; n=20$; Fig. 4A).

\subsection{Pigments and POC in sediment traps}

In contrast to the water column, there was no significant correlation between the fluxes of Chl-a measured with ST $\left(C h l-a_{\mathrm{ST}}\right)$ and $F_{\mathrm{C}, \mathrm{ST}}$, neither at $100 \mathrm{~m}(p>0.05$; Spearman correlation coefficient, $\rho=-0.03 ; n=11)$ nor $300 \mathrm{~m}(p>0.05, \rho=0.26, n=11$, Fig. 4B). Both Chl- $a_{\mathrm{ST}}$ fluxes and $F_{\mathrm{C}, \mathrm{ST}}$ decreased with depth (except Chl- $a_{\mathrm{ST}}$ flux at station $\mathrm{C114}$ ), although the decrease was stronger for POC at most stations (Fig. 5A and Table 5).

Maximum Chl- $a_{\mathrm{ST}}$ flux was recorded at station $\mathrm{C98}$ $\left(0.79 \mathrm{mg} \mathrm{m}^{-2} \mathrm{~d}^{-1}\right.$ at $\left.100 \mathrm{~m}\right)$, whereas minimum $C h l-a_{\mathrm{ST}}$ flux was observed at station $86\left(0.11 \mathrm{mg} \mathrm{m}^{-2} \mathrm{~d}^{-1}\right.$ at $\left.300 \mathrm{~m}\right)$. Fluxes of total pheopigments (TPheo, i.e. sum of pheophytin-a, pyropheophytin-a, pheophorbide-a, and pyropheophorbide-a pigments) were generally higher at $100 \mathrm{~m}$ than at $300 \mathrm{~m}$ except at stations C91 and C114 (Fig. 5A). Maximum TPheo fluxes were recorded at station 87 (2.67 and $1.27 \mathrm{mg} \mathrm{m}^{-2} \mathrm{~d}^{-1}$ at 100 and $300 \mathrm{~m}$, respectively). Ratios of TPheo/Chl$a_{\mathrm{ST}}$ were generally higher at $100 \mathrm{~m}$ than at $300 \mathrm{~m}$ except at station C91. TPheo/Chl- $a_{\mathrm{ST}}$ ratios above 1 were recorded at most of the investigated stations except at 137, 139, C98, C136 and C140 (Fig. 5A). Among the marker pigments, fluxes of fucoxanthin were much higher than other pigments (Fig. 5B) and the phytoplankton size classification showed that more than $80 \%$ of the phytoplankton were microphytoplankton (Fig. 5C).
(B)

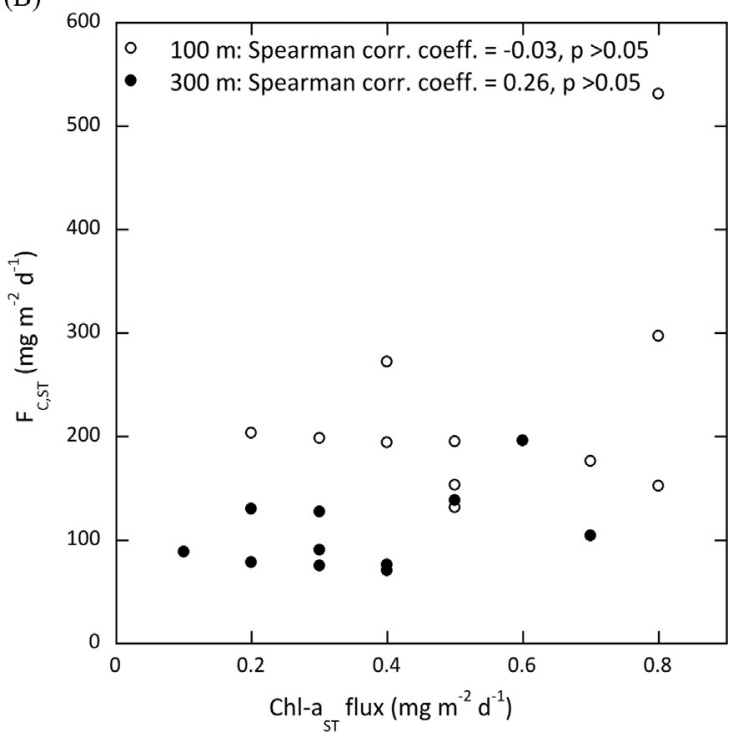

Fig. 4. POC vs. Chl-a: (A) inventories in the upper $100 \mathrm{~m}$ of the water column and (B) fluxes measured with sediment traps at $100 \mathrm{~m}$ (in white) and $300 \mathrm{~m}$ (in black). 

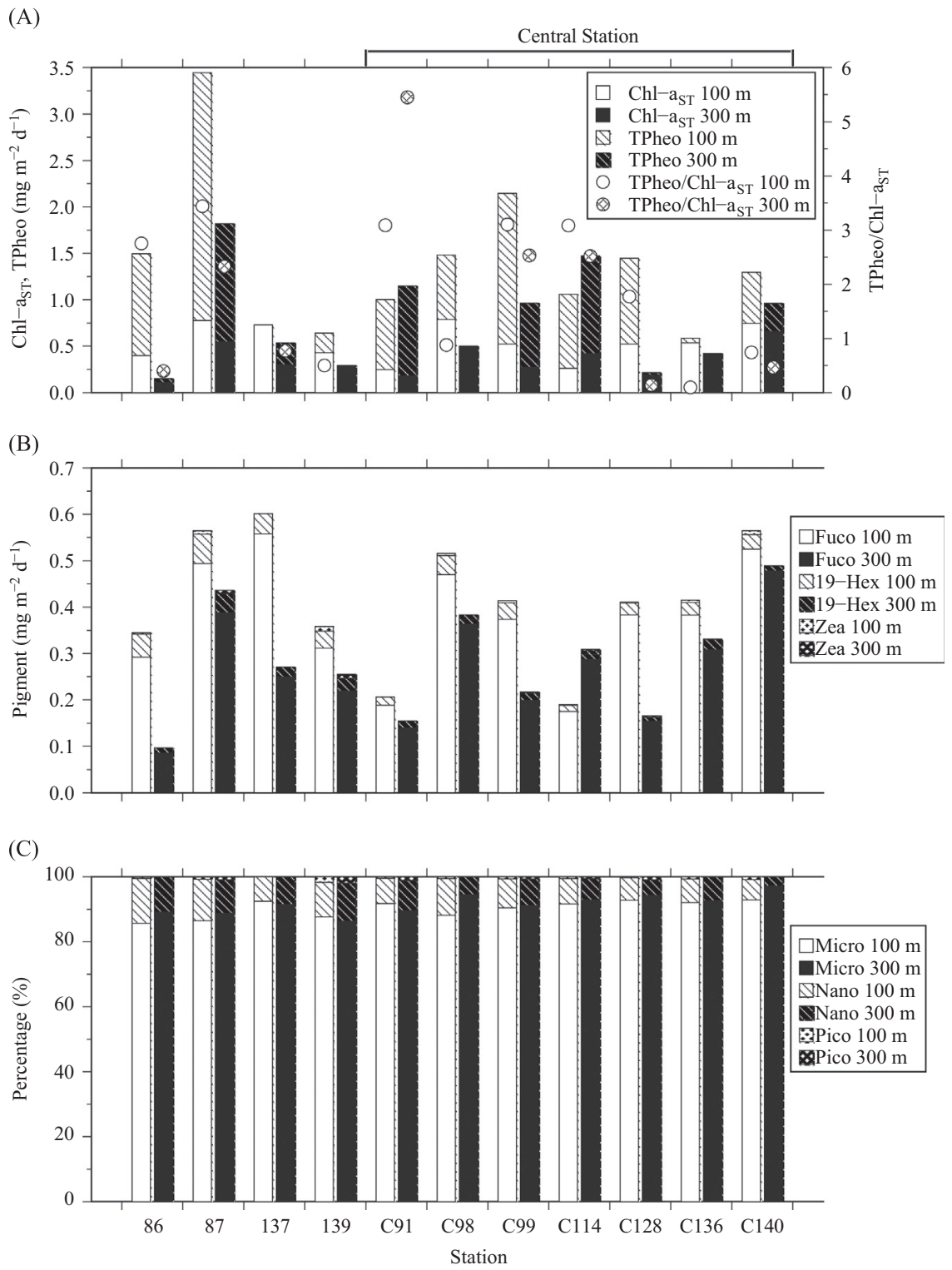

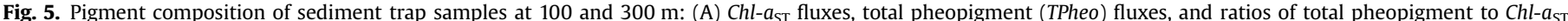

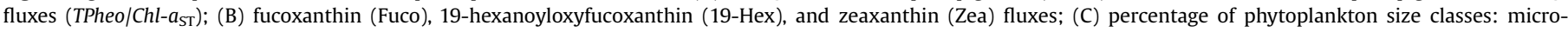
phytoplankton (Micro), nanophytoplankton (Nano) and picophytoplankton (Pico).

\section{Discussion}

4.1. ${ }^{234}$ Th fluxes

\subsubsection{Seawater approach vs. sediment traps}

In this study, the ${ }^{234} \mathrm{Th}$ fluxes were estimated using the seawater approach and sediment traps. The SW approach integrates about 5 weeks before sampling $\left({ }^{234} \mathrm{Th}\right.$ mean life $=35$ days $)$, while ST provide information at the sampling time. In general, as shown in Section 3.2, the ${ }^{234} \mathrm{Th}$ fluxes based on these techniques were not significantly different at $100 \mathrm{~m}$. This agreement indicates a sustained export rate in the weeks prior to and during the sampling period, suggesting export fluxes at steady state.

At $300 \mathrm{~m}$ the $F_{\mathrm{Th}, \mathrm{ST}}$ were about 3 times lower than the $F_{\mathrm{Th}, \mathrm{SW}}$. A review by Buesseler et al. (2007) suggested that ${ }^{234}$ Th-bearing particles were under-trapped by a factor of about 2 and suggested some processes that could be sources of trap error, such as undercollection of slow settling particles by hydrodynamic bias, particle solubilisation within the trap before sample processing, and "swimmer" related artefacts. Haskell et al. (2013) reported that ST collected about $\leq 20 \%$ of the $F_{\mathrm{Th}, \mathrm{SW}}$ in two consecutive years and proposed that the main cause of this mismatch was the undertrapping of small, ${ }^{234}$ Th-enriched slow sinking particles. Additionally, the active transport of surface-derived particles to hundreds of metres down via zooplankton migration (e.g. Angel, 1989) is another factor that may lead to underestimation of the particle export based on ST. Here, we tried to minimise the sources of error by using two surface floats and 12 buoyancy balls as wave breakers, while the cylinders of the ST were gimbal mounted. In addition, samples were processed within $24 \mathrm{~h}$ after collection to decrease the impact of solubilisation and zooplankton swimmers on material, which were picked under a binocular microscope.

Buesseler et al. (2007) also suggested that the mismatch between the SW approach and ST could be related to the use of inaccurate assumptions in the ${ }^{234} \mathrm{Th}$ model. The exclusion of physical processes in our study could introduce a significant error on the $F_{\mathrm{Th}, \mathrm{SW}}$ estimates at $300 \mathrm{~m}(\sim 50 \%$, see Section 3.2.1). Besides, in a late stage of a bloom, the SS assumption may lead to an overestimation of the $F_{\mathrm{Th}, \mathrm{sw}}$ if higher export occurred before sampling (within the ${ }^{234} \mathrm{Th}$ time scale). However, similar $F_{\mathrm{Th}, \mathrm{SW}}$ 
were found over the entire study area at both 100 and $300 \mathrm{~m}$ (Fig. 3), irrespectively of phytoplankton biomass (see Section 3.5). This indicates that ${ }^{234} \mathrm{Th}$ fluxes probably did not change significantly during the weeks before our arrival and, therefore, the SS model gives reasonable estimates of ${ }^{234} \mathrm{Th}$ export flux.

\subsubsection{Results and comparison with other studies}

On average, ${ }^{234} \mathrm{Th}$ fluxes at 100 and $300 \mathrm{~m}$ were $2100 \pm 700$ and $2000 \pm 1000 \mathrm{dpm} \mathrm{m}^{-2} \mathrm{~d}^{-1}$, respectively. Hence, the fluxes were high and quite similar over the entire study area, despite the differences observed in Chl- $a_{\mathrm{SW}}$ inventories (see Section 3.5) and production rates (Hoppe et al., 2017). However, satellite images show widespread high Chl-a concentrations in January 2012 (data not shown). Thus, stations with low phytoplankton biomass and production rates (e.g. stations 139 and (136) but high $F_{\mathrm{Th}}$ evidenced a temporal decoupling between production and export. Buesseler et al. (2003, 2001a), Rutgers van der Loeff et al. (2011) and Henson et al. (2015) showed that export lags production by up to 1-2 months in the Southern Ocean, which is a time frame compatible with the present study.

Our $F_{\mathrm{Th}}$ estimates at $100 \mathrm{~m}$ are within the range of values for blooms during their peak and/or decline occurring in the Southern Ocean, either in land remote areas (Rutgers van der Loeff et al., 1997) or near islands (Morris et al., 2007; Savoye et al., 2008). In contrast, our estimates are higher than the $F_{\mathrm{Th}}$ of $\leq 1000 \mathrm{dpm} \mathrm{m}^{-2} \mathrm{~d}^{-1}$ reported during the onset of a bloom by Planchon et al. (2015), and during the artificial iron fertilisation experiments SOIREE (Charette and Buesseler, 2000), EisenEx (Rutgers van der Loeff and Vöge, 2001) and LOHAFEX (Martin et al., 2013). However, the SOFeX-South experiment revealed an increase of particle fluxes after fertilisation, which resulted in $F_{\mathrm{Th}}$ of $\sim 1800 \mathrm{dpm} \mathrm{m}^{-2} \mathrm{~d}^{-1}$ at the MLD (Buesseler et al., 2005, 2004). The variability within the plankton community structure and different sampling time strategies among these experiments most likely played a crucial role in the variety of results obtained (Boyd et al., 2007; Buesseler et al., 2004).

A release of ${ }^{234} \mathrm{Th}$ from sinking particles, either via remineralisation or disaggregation, was evidenced by a $40 \%$ decrease of the $F_{\mathrm{Th}, \mathrm{ST}}$ between 100 and $300 \mathrm{~m}$ at the majority of the stations. However, the seawater approach did not show excesses of ${ }^{234} \mathrm{Th}$ in the depth range $100-300 \mathrm{~m}$ at any station. As a result, ${ }^{234} \mathrm{Th}$ flux attenuation from 100 to $300 \mathrm{~m}$ estimated using the two methods was different at 3 out of 7 stations, taking into account the large uncertainties of the $F_{\mathrm{Th}, \mathrm{sw}}$ estimates at $300 \mathrm{~m}$ (16-48\%, Table 3$)$. The potential impact of advection on the $F_{\mathrm{Th}, \mathrm{SW}}$ estimates at $300 \mathrm{~m}$ (see Section 3.2.1) together with a low resolution of the seawater sampling between 100 and $300 \mathrm{~m}$ (2-3 samples) likely explain most of the disagreement between the ST and SW approaches on this issue. Remineralisation and/or particle break-up was also indicated in previous studies in the Southern Ocean (Buesseler et al., 2005; Planchon et al., 2013; Rutgers van der Loeff et al., 2011; Savoye et al., 2004; Usbeck et al., 2002). In our study, $F_{\mathrm{Th}, \mathrm{ST}}$ were attenuated between 100 and $300 \mathrm{~m}$ at the first 4 visits of the central station, but not at stations C128 and C140 (Table 3), indicating that attenuation of $F_{\mathrm{Th}, \mathrm{ST}}$ in this depth range became negligible at the end of the sampling period. This observation is similar to one of the major findings of the SOFeX-South experiment: the attenuation of $F_{\mathrm{Th}}$ with depth disappeared as the bloom progressed (Buesseler et al., 2005). This was attributed to changes in the nature of the sinking particles (less labile or more rapidly sinking) and/or less efficient biological and physical processes responsible for particle break-up and consumption below the bloom.

\section{2. $P O C /{ }^{234}$ Th and $P O N /{ }^{234}$ Th ratios in particles}

$\mathrm{C} / \mathrm{Th}$ and $\mathrm{N} / \mathrm{Th}$ ratios were $>10 \mu \mathrm{mol} \mathrm{Cdpm}^{-1}$ (average: $15 \pm 5 \mu \mathrm{mol} \quad \mathrm{Cdpm}^{-1}$ ) and $>1 \mu \mathrm{mol} \mathrm{Ndpm}^{-1}$ (average: $2 \pm 1 \mu \mathrm{mol} \mathrm{N} \mathrm{dpm}{ }^{-1}$ ), respectively, in all samples collected either with ST or ISP $(>53 \mu \mathrm{m})$ at $100 \mathrm{~m}$. Overall, these values were higher than those reported by most studies conducted in the Southern Ocean (Buesseler et al., 2005, 2001a; Coppola et al., 2005; Jacquet et al., 2011; Martin et al., 2013; Morris et al., 2007; Planchon et al., 2013; Rutgers van der Loeff et al., 2011, 1997; Savoye et al., 2008), but similar to others (Cochran et al., 2000; Puigcorbé et al., 2017; Rutgers van der Loeff et al., 2002; Smetacek et al., 2012). Multiple factors may have played a role in shaping the $\mathrm{C} / \mathrm{Th}$ and N/Th ratios, such as particle source, sinking velocity, Th speciation and remineralisation of $\mathrm{C}, \mathrm{N}$ and ${ }^{234} \mathrm{Th}$ associated with sinking particles (Buesseler et al., 2006). Buesseler (1998) and Buesseler et al. (2006) hypothesised that high C/Th ratios encountered in productive regimes and high latitude areas may be related to the dominance of sinking of large cells, such as diatoms. This was explained by the fact that diatoms have a high volume relative to surface area ( $V: S A)$, and hence high $C /$ Th ratios because $C$ varies as a function of volume, whereas Th adsorption varies as a function of surface area. In our study, the dominance of fucoxanthin, a marker pigment for diatoms, and microphytoplankton in trap material (Fig. 5B and C) revealed that diatoms were the major phytoplankton group contributing to vertical fluxes. Additionally, according to microscopic analyses (C. Klaas, pers. comm.), the needle-shaped Pseudo-nitzschia lineola and the large centric diatom Dactyliosolen antarcticus dominated the bloom, with significant contributions from Fragilariopsis kerguelensis as well as other Pseudo-nitzschia, Rhizosolenia and Chaetoceros species. Thus, diatoms with a high $V: S A$, including Dactyliosolen antarcticus and Chaetoceros spp. played a relevant role in the bloom, which could be responsible for the high ratios observed.

$\mathrm{C} / \mathrm{Th}$ and $\mathrm{N} / \mathrm{Th}$ ratios at $300 \mathrm{~m}$ were, on average, about $30 \%$ lower than at $100 \mathrm{~m}$. The reduction of $\mathrm{C} / \mathrm{Th}$ ratios with depth is commonly observed (Buesseler et al., 2006). It is likely due to the production of ${ }^{234} \mathrm{Th}$ in the entire water column leading to additional adsorption of ${ }^{234} \mathrm{Th}$ onto particles at depth, which compensates its decay, and a preferential remineralisation of POC with respect to ${ }^{234} \mathrm{Th}$ (Rutgers van der Loeff et al., 2002). The same reasons would apply to PON.

The $\mathrm{C} / \mathrm{N}$ ratios averaged $8 \pm 1$ and $7 \pm 1$ for ST and ISP samples, respectively, and were within the range of values previously reported during bloom events (Martin et al., 2013; Morris et al., 2007; Savoye et al., 2008), with a diverse composition of the dominant particle type (diatoms: Salter et al., 2007; faecal material: Ebersbach and Trull, 2008; Ebersbach et al., 2014).

\subsection{POC and PON fluxes at $100 \mathrm{~m}$}

POC and PON export fluxes at $100 \mathrm{~m}$ averaged $26 \pm 15 \mathrm{mmol}$ $\mathrm{C} \mathrm{m}^{-2} \mathrm{~d}^{-1}$ (range: $11-67 \mathrm{mmol} \mathrm{C} \mathrm{m}^{-2} \mathrm{~d}^{-1}$ ) and $4 \pm 2 \mathrm{mmol}$ $\mathrm{N} \mathrm{m}^{-2} \mathrm{~d}^{-1}$ (range: $1.6-12 \mathrm{mmol} \mathrm{N} \mathrm{m}^{-2} \mathrm{~d}^{-1}$, Table 5), respectively. The $F_{C}$ are high in relation to the average fluxes compiled by Le Moigne et al. (2013) and Maiti et al. (2013). Le Moigne et al. (2013) reported an average $F_{\mathrm{C}}$ of $9 \pm 13 \mathrm{mmol} \mathrm{C} \mathrm{m} \mathrm{C}^{-2} \mathrm{~d}^{-1}(n=726$; range: $<0-125 \mathrm{mmol} \mathrm{C} \mathrm{m}{ }^{-2} \mathrm{~d}^{-1}$ ) for the global ocean, and $13 \pm 14 \mathrm{mmol}$

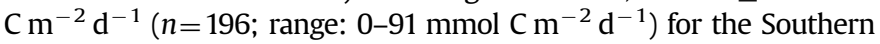
Ocean. Maiti et al. (2013) reported a range of $F_{C}$ from 1 to $50 \mathrm{mmol}$ $\mathrm{C} \mathrm{m}^{-2} \mathrm{~d}^{-1}$ for the Southern Ocean, averaging $11 \pm 8 \mathrm{mmol}$ $\mathrm{C} \mathrm{m}^{-2} \mathrm{~d}^{-1}(n=140)$.

Considering other natural blooms observed in the Southern Ocean, our estimates of $F_{C}$ are comparable to those reported in KEOPS (average: $23 \pm 4 \mathrm{mmol} \mathrm{C} \mathrm{m}^{-2} \mathrm{~d}^{-1}$, Savoye et al., 2008), the JGOFS Southern Ocean expedition (range: $20-39 \mathrm{mmol} \mathrm{C} \mathrm{m}^{-2} \mathrm{~d}^{-1}$, 
Rutgers van der Loeff et al., 1997), and the CROZEX project (average: $14 \pm 4 \mathrm{mmol} \mathrm{C} \mathrm{m}{ }^{-2} \mathrm{~d}^{-1}$, Morris et al., 2007). Our estimates of $F_{\mathrm{N}}$ are also similar to the results from KEOPS and CROZEX (Morris et al., 2007; Savoye et al., 2008). In contrast, the $F_{\mathrm{C}}$ are higher than those reported in KEOPS II (average: $7 \pm 2 \mathrm{mmol} \mathrm{C} \mathrm{m}^{-2} \mathrm{~d}^{-1}$, Planchon et al., 2015) for a bloom during its growing stage. On the other hand, the $F_{\mathrm{C}}$ determined during SOIREE (Charette and Buesseler, 2000), SOFeX-South (Buesseler et al., 2005) and LOHAFEX (Martin et al., 2013) were clearly lower (average $\leq 8 \mathrm{mmol}$ $\mathrm{C} \mathrm{m}^{-2} \mathrm{~d}^{-1}$ ) than in this study. In the case of LOHAFEX, it was explained by silica limitation that prevented diatom growth. The low $F_{\mathrm{C}}$ measured during SOIREE and SOFeX-South were likely due to a limited sampling period. However, the artificially induced bloom during EIFEX (Smetacek et al., 2012) led to an extraordinarily high $F_{\mathrm{C}}\left(\sim 80 \mathrm{mmol} \mathrm{C} \mathrm{m}^{-2} \mathrm{~d}^{-1}\right)$ with a high export efficiency. Thus, the high export fluxes found in our study are comparable to other studies of the later stages of natural and iron fertilised blooms in the Southern Ocean that were not silica limited.

\section{Table 6}

Export and transfer efficiencies using the POC export estimated from the ST, SWST and SWISP methods (see text for further details).

\begin{tabular}{|c|c|c|c|c|c|c|}
\hline \multirow[t]{2}{*}{ Station } & \multicolumn{3}{|c|}{ Export efficiency (\%) } & \multicolumn{3}{|c|}{ Transfer efficiency (\%) } \\
\hline & ST & SWST & SWISP & ST & SWST & SWISP \\
\hline 86 & 7.5 & $10 \pm 1$ & & 45 & $60 \pm 30$ & \\
\hline 87 & & & & 37 & $80 \pm 30$ & \\
\hline 137 & 13 & $47 \pm 5$ & & 43 & & \\
\hline 139 & 34 & $40 \pm 5$ & $100 \pm 10$ & 47 & $60 \pm 20$ & $30 \pm 10$ \\
\hline C91 & 7.2 & $14 \pm 2$ & $11 \pm 1$ & 38 & $50 \pm 20$ & $60 \pm 20$ \\
\hline C98 & & & & 47 & & \\
\hline C99 & & & & 46 & & \\
\hline C114 & 8.1 & & & 35 & & \\
\hline C128 & 9.2 & $24 \pm 3$ & & 84 & $140 \pm 30$ & \\
\hline C136 & 12 & & & 58 & & \\
\hline C140 & 7.6 & $17 \pm 2$ & & 68 & $90 \pm 20$ & \\
\hline
\end{tabular}

(A)

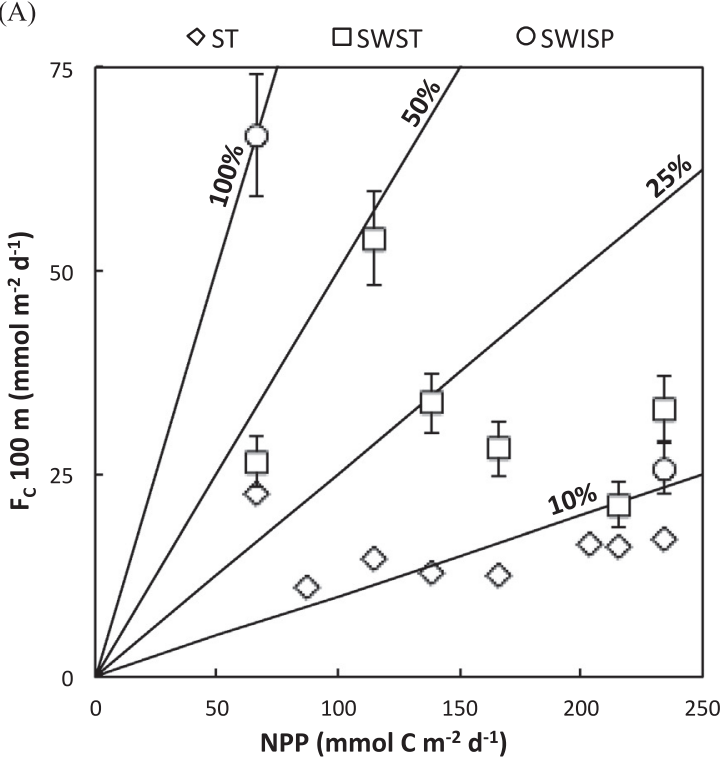

\subsection{Export efficiency}

The export efficiency is a useful parameter to illustrate the strength of the biological pump, even though production and export operate at distinct time scales (Buesseler and Boyd, 2009). It should also be noted the temporal mismatch between the measurements of production and export: $24 \mathrm{~h}$ incubation for NPP (Hoppe et al., 2017), 15-72 h deployment for ST and several weeks of integration for the SW approach. We assessed the export efficiency by dividing the $F_{\mathrm{C}}$ at $100 \mathrm{~m}$, either from the SW methods or ST, by the NPP integrated down to $100 \mathrm{~m}$ (Hoppe et al., 2017).

The export efficiency within the bloom averaged $23 \pm 24 \%$ (range: 7-100\%; Table 6 and Fig. 6A), taking into account all the techniques used to estimate the export of POC (ST, SWST, SWISP). The export efficiency was around $10 \%$ according to the ST, which is common in the open ocean (Buesseler, 1998), whereas it was around $25 \%$ considering the SWST method. Besides these differences, the export efficiency was always $\leq 50 \%$ for the ST and SWST methods, contrasting with export efficiencies $>50 \%$ reported during blooms at high latitudes, mostly characterized by large diatoms (Buesseler, 1998; Smetacek et al., 2012) and a combination of Phaeocystis and diatoms (Buesseler et al., 2003; Poulton et al., 2007). Other Southern Ocean studies (Buesseler et al., 2005; Planchon et al., 2015) have also reported export efficiencies of $\sim 10 \%$ during not yet declining diatom blooms, where low POC export fluxes were measured $\left(7-8 \mathrm{mmol} \mathrm{C} \mathrm{m}^{-2} \mathrm{~d}^{-1}\right)$. In contrast, during our study the bloom was declining, which led to high downward fluxes. We propose that this relatively low strength of the biological pump was likely related to an active recycling of carbon and nutrients in surface waters. Only for one station (139), which evidenced a temporal decoupling between production and export (lowest $C h l-a_{\mathrm{Sw}}$ inventories and NPP rates), the export efficiency was $>30 \%$ according to all techniques. Indeed, we found an inverse relationship between export efficiency and NPP $(p<0.05$; ST method: $\rho=-0.95, n=8$; SWST method: $\rho=-0.89$, $n=6$ ) supporting recent observations (Cavan et al., 2015; Laurenceau-Cornec et al., 2015; Maiti et al., 2013). This relationship could be explained by a combination of temporal decoupling between primary production and export (Henson et al., 2015; Puigcorbé et al., 2017), and other processes such as zooplankton

(B)

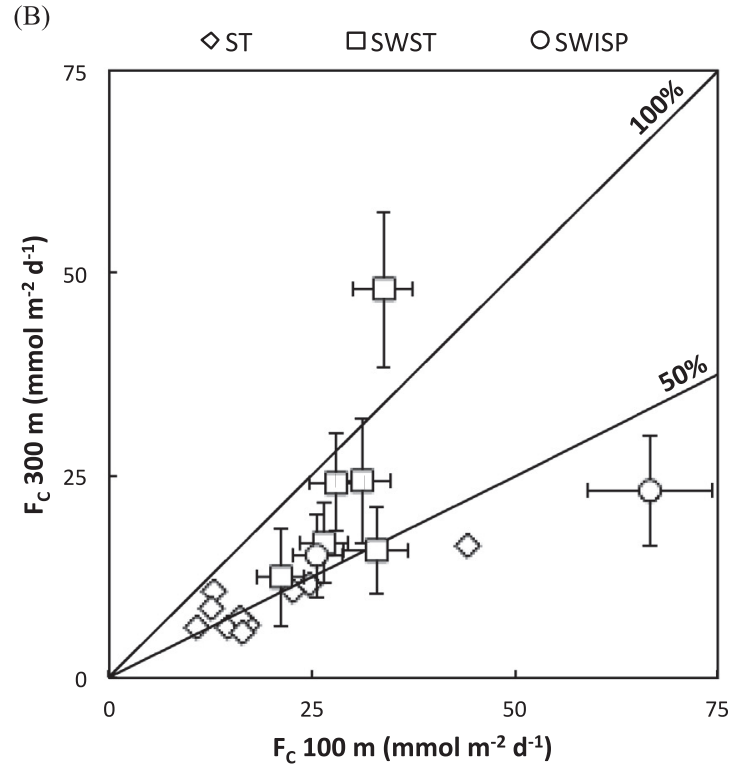

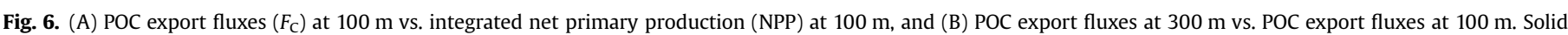

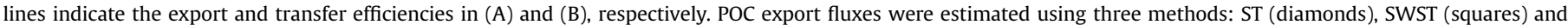
SWISP (circles, see text for further details). 
grazing (Cavan et al., 2015), bacterial activity and recycling efficiency (Maiti et al., 2013).

\subsection{Transfer efficiency}

The upper $300 \mathrm{~m}$ of the water column is where intense biological and physical processes transform the size distribution of particles and thus modify the flux of particles to the mesopelagic layer (Guidi et al., 2009). To account for the change of the $F_{C}$ magnitude within the upper twilight zone, we estimated the transfer efficiency by dividing the $F_{\mathrm{C}}$ at $300 \mathrm{~m}$ by those at $100 \mathrm{~m}$.

The transfer efficiency averaged $59 \pm 26 \%$ (range: $35->100 \%$; Table 6 and Fig. 6B) with a general discrepancy among techniques $<30 \%$. Most of the transfer efficiencies were higher than the estimates presented by (i) Schlitzer (2002): 40\% for the same depth range using an inverse model based on observations of temperature, salinity and nutrient concentrations; and (ii) Guidi et al. (2009): < 42\% when microphytoplankton dominated the phytoplankton community based on a world-ocean analysis. Guidi et al. (2009) showed that maximum values of $F_{C}$ at $400 \mathrm{~m}$ were associated with a dominance of microphytoplankton in the euphotic zone, although the flux experienced a sharp decrease from 100 to $300 \mathrm{~m}$. In our study, the transfer efficiency at the central station was lower during the first 4 visits (C91-C114: $42 \pm 6 \%$ ) than during the last 3 (C128-C140: $70 \pm 10 \%$ ) according to the ST results (Table 6). This change coincided with a decrease of the TPheo/Chl- $a_{\mathrm{ST}}$ ratio in the trap material from the first group of stations to the second: from $2.5 \pm 1.1$ to $0.9 \pm 0.8$ at $100 \mathrm{~m}$ and from $3.5 \pm 1.7$ to $0.3 \pm 0.2$ at $300 \mathrm{~m}$ (Fig. $5 \mathrm{~A}$ ). Pheopigments are degraded Chl-a products that are associated with grazing activity and phytoplankton senescence (Wright et al., 2010). Thus, this observation indicates that when the transfer efficiency was higher, the organic material being exported was fresher. Indeed, there is a negative relationship between $T P h e o / C h l-a_{\mathrm{ST}}$ ratios at $100 \mathrm{~m}$ and the transfer efficiency of POC from 100 to $300 \mathrm{~m}$ derived from ST $(p<0.01 ; \rho=-0.77, n=10)$. This correlation highlights the relevance of the particle composition sinking out from the ocean surface in shaping the efficiency of the biological pump. Buesseler and Boyd (2009) pointed out that very high transfer efficiencies are attributed to direct sinking of algae with low flux attenuation. Here, more than $60 \%$ of the Chl- $a_{\mathrm{ST}}$ and fucoxanthin fluxes at $100 \mathrm{~m}$ reached $300 \mathrm{~m}$ (Fig. 5A and $\mathrm{B}$ ), which highlights the contribution of diatoms to vertical fluxes in the study area. In particular, the direct sinking of diatoms might be the main explanation for the high transfer efficiencies at stations C136 and C140, since at these locations the high fucoxanthin fluxes at $100 \mathrm{~m}$ ( $>0.4 \mathrm{mg} \mathrm{m}^{-2} \mathrm{~d}^{-1}$ ) showed a decrease of only $\sim 10-20 \%$ at $300 \mathrm{~m}$, and the TPheo/Chl- $a_{\mathrm{ST}}$ ratios were $<1$ (Fig. 5A and B). Indeed, a study by Cedhagen et al. (2014) from the same cruise showed that abyssal benthic foraminifera at $\sim 4000 \mathrm{~m}$ were feeding on fresh phytodetritus. This indicates that at least part of the phytoplankton was transported to the seabed.

The lack of relationship between $C h l-a_{\mathrm{ST}}$ and $F_{\mathrm{C}, \mathrm{ST}}$ at both 100 and $300 \mathrm{~m}$ depth (Fig. 4B), however, indicated that reprocessed material or dead phytoplankton also contributed significantly to the export fluxes at most stations. The high fluxes of pheopigments ( $>0.6 \mathrm{mg} \mathrm{m}^{-2} \mathrm{~d}^{-1}$ ) together with TPheo/Chl- $a_{\mathrm{ST}}$ ratios $>1$ (Fig. 5A) at stations 87, C91, C99 and C114 at 100 and 300 m may be associated with grazing activity and, hence, indicate the contribution of faecal pellets to sinking fluxes. Preliminary results confirmed a significant abundance of faecal pellets in trap material during our survey (Iversen and Klaas, 2013), although this should be validated by quantitative analyses in the future. Specifically, at station C114 the TPheo, Chl- $a_{\mathrm{ST}}$ and fucoxanthin fluxes increased from 100 to $300 \mathrm{~m}$ (Fig. $5 \mathrm{~A}$ and $\mathrm{B}$ ), which may have been due to zooplankton consumption of diatoms in the euphotic zone and release of faecal pellets between 100 and $300 \mathrm{~m}$. Therefore, production of faecal pellets and zooplankton vertical migration might have modulated the transfer efficiency in this study. Similar conclusions have been reached by Buesseler and Boyd (2009) and Cavan et al. (2015).

\section{Conclusions}

We measured downward fluxes of POC and PON during the decline of a vast diatom bloom in a land-remote area of the Atlantic sector of the Southern Ocean. Our main conclusions are:

1) The simultaneous use of sediment traps and the ${ }^{234} \mathrm{Th} /{ }^{238} \mathrm{U}$ proxy evidenced that ${ }^{234} \mathrm{Th}$ export rates at $100 \mathrm{~m}$ were high and constant in the weeks prior to and during the survey.

2) Stations distributed over an area of $8000 \mathrm{~km}^{2}$ showed similar vertical export fluxes in spite of the heterogeneity in phytoplankton standing stocks and productivity, indicating a decoupling between production and export.

3) The diatom bloom led to high POC export fluxes at $100 \mathrm{~m}$ $\left(26 \pm 15 \mathrm{mmol} \mathrm{C} \mathrm{m} \mathrm{C}^{-2} \mathrm{~d}^{-1}\right)$, although the export efficiencies were generally low $(<20 \%)$ in comparison to other diatom blooms at high latitudes. An active recycling of carbon and nutrients in surface waters was likely the reason for the low export efficiencies.

4) In contrast to the low export efficiencies at $100 \mathrm{~m}$ depth, the transfer efficiency of POC between 100 and $300 \mathrm{~m}$ was high during the entire study period $(\sim 60 \%)$, partly driven by the sinking of fresh diatoms. Faecal pellets and the active transport of POC linked to zooplankton vertical migration may have also contributed significantly to vertical fluxes. If we are to understand the efficiency of the biological pump in the Southern Ocean, these processes should be further investigated in the future.

\section{Acknowledgements}

We are very grateful to the crew and scientific party of the R/V Polarstern ANT-XXVIII/3 expedition for their support at sea during more than two months. Thanks to the European Space Agency (ESA) for OC-CCI data. We wish to acknowledge I. Stimac for her assistance with the cruise preparation and ICPMS analyses, S. Wiegmann for her help with the HPLC analysis in sediment trap samples, and M. Donnelly for his support deploying the in-situ pumps. The authors acknowledge C.J.M. Hoppe, V.H. Strass, D. Wolf-Gladrow and M.A. Soppa for providing valuable comments on earlier drafts. The manuscript was improved by comments from F. Planchon and an anonymous reviewer. This project was partly supported by the Ministerio de Ciencia e Innovación (CTM201114027-E, Spain) and the Generalitat de Catalunya to the research group MERS (2014 SGR-1356). M.R.-M. and V.P. acknowledge financial support through Ph.D. fellowships (AP2010-2510 and AP2009-4733, respectively) from the Spanish government. Support for the research of P.M. was received through a Gledden Visiting Fellowship awarded by the Institute of Advanced Studies at The University of Western Australia. Funding to W.C. and to A.B. was supplied partly by the Helmholtz Innovation Fund Phytooptics. M.H.I. was supported by the Helmholtz Association, the Alfred Wegener Institute for Polar and Marine Research, HGF Young Investigator Group "SeaPump", and the DFG-Research Center/ Cluster of Excellence "The Ocean in the Earth System". 


\section{References}

Angel, M.V., 1989. Does mesopelagic biology affect the vertical flux?. In: Berger, W.H. Smetacek, V.S., Wefer, G. (Eds.), Productivity of the oceans: Present and past. Geol. J., John Wiley and Sons, New York. 10.1002/gj.3350260119.

Assmy, P., Smetacek, V., Montresor, M., Klaas, C., Henjes, J., Strass, V.H., Arrieta, J.M., Bathmann, U., Berg, G.M., Breitbarth, E., Cisewski, B., Friedrichs, L., Fuchs, N. Herndl, G.J., Jansen, S., Krägefsky, S., Latasa, M., Peeken, I., Röttgers, R., Scharek, R., Schüller, S.E., Steigenberger, S., Webb, A., Wolf-Gladrow, D., 2013. Thickshelled, grazer-protected diatoms decouple ocean carbon and silicon cycles in the iron-limited Antarctic Circumpolar Current. Proc. Natl. Acad. Sci. USA 110, 20633-20638. http://dx.doi.org/10.1073/pnas.1309345110.

Barlow, R., Cummings, D., Gibb, S., 1997. Improved resolution of mono- and divinyl chlorophylls $\mathrm{a}$ and $\mathrm{b}$ and zeaxanthin and lutein in phytoplankton extracts using reverse phase C-8 HPLC. Mar. Ecol. Ser. 161, 303-307. http://dx.doi.org/10.3354/ meps161303.

Boyd, P.W., Jickells, T., Law, C.S., Blain, S., Boyle, E.A., Buesseler, K.O., Coale, K.H., Cullen, J.J., de Baar, H.J.W., Follows, M., Harvey, M., Lancelot, C., Levasseur, M., Owens, N.P.J., Pollard, R., Rivkin, R.B., Sarmiento, J., Schoemann, V., Smetacek, V., Takeda, S., Tsuda, A., Turner, S., Watson, A.J., 2007. Mesoscale iron enrichment experiments 1993-2005: synthesis and future directions. Science 315, 612-617. http://dx.doi.org/10.1126/science.1131669.

Buesseler, K.O., 1998. The decoupling of production and particulate export in the surface ocean. Glob. Biogeochem. Cycles 12, 297-310. http://dx.doi.org/10.1029/ 97GB03366.

Buesseler, K.O., Andrews, J.E., Pike, S.M., Charette, M.A., 2004. The effects of iron fertilization on carbon sequestration in the Southern Ocean. Science 304, 414-417. http://dx.doi.org/10.1126/science.1086895.

Buesseler, K.O., Andrews, J.E., Pike, S.M., Charette, M.A., Goldson, L.E., Brzezinski, M. A., Lance, V.P., 2005. Particle export during the Southern Ocean Iron Experiment (SOFeX). Limnol. Oceanogr. 50, 311-327. http://dx.doi.org/10.4319/ lo.2005.50.1.0311.

Buesseler, K.O., Antia, A.N., Chen, M., Fowler, S.W., Gardner, W.D., Gustafsson, O., Harada, K., Michaels, A.F., Rutgers van der Loeff, M.M., Sarin, M., Steinberg, D.K., Trull, T., 2007. An assessment of the use of sediment traps for estimating upper ocean particle fluxes. J. Mar. Res. 65, 345-416,

Buesseler, K.O., Bacon, M.P., Cochran, J.K., Livingston, H.D., 1992. Carbon and nitrogen export during the JGOFS North Atlantic Bloom experiment estimated from ${ }^{234} \mathrm{Th}:{ }^{238} \mathrm{U}$ disequilibria. Deep-Sea Res. Part I Oceanogr. Res. Pap. 39, 1115-1137. http://dx.doi.org/10.1016/0198-0149(92)90060-7.

Buesseler, K.O., Ball, L., Andrews, J., Cochran, J.K., Hirschberg, D.J., Bacon, M.P., Fleer, A., Brzezinski, M., 2001a. Upper ocean export of particulate organic carbon and biogenic silica in the Southern Ocean along $170^{\circ} \mathrm{W}$. Deep-Sea Res. Part II Top. Stud. Oceanogr. 48, 4275-4297. http://dx.doi.org/10.1016/S0967-0645(01)00089-3.

Buesseler, K.O., Barber, R.T., Dickson, M.L., Hiscock, M.R., Moore, J.K., Sambrotto, R., 2003. The effect of marginal ice-edge dynamics on production and export in the Southern Ocean along 170 degrees W. Deep-Sea Res. Part II Top. Stud. Oceanogr. 50, 579-603. http://dx.doi.org/10.1016/S0967-0645(02)00585-4.

Buesseler, K.O., Benitez-Nelson, C., Rutgers van der Loeff, M.M., Andrews, J., Ball, L., Crossin, G., Charette, M.A., 2001b. An intercomparison of small- and largevolume techniques for thorium-234 in seawater. Mar. Chem. 74, 15-28. http: //dx.doi.org/10.1016/S0304-4203(00)00092-X.

Buesseler, K.O., Benitez-Nelson, C.R., Moran, S.B., Burd, A., Charette, M., Cochran, J. K., Coppola, L., Fisher, N.S., Fowler, S.W., Gardner, W.D., Guo, L.D., Gustafsson, Ö., Lamborg, C., Masqué, P., Miquel, J.C., Passow, U., Santschi, P.H., Savoye, N., Stewart, G., Trull, T., 2006. An assessment of particulate organic carbon to thorium-234 ratios in the ocean and their impact on the application of ${ }^{234} \mathrm{Th}$ as a POC flux proxy. Mar. Chem. 100, 213-233. http://dx.doi.org/10.1016/j. marchem.2005.10.013.

Buesseler, K.O., Boyd, P., 2009. Shedding light on processes that control particle export and flux attenuation in the twilight zone of the open ocean. Limnol. Oceanogr. 54, 1210-1232. http://dx.doi.org/10.4319/lo.2009.54.4.1210.

Buesseler, K.O., Michaels, A.F., Siegel, D.A., Knap, A.H., 1994. A three dimensional time-dependent approach to calibrating sediment trap fluxes. Glob. Biogeochem. Cycles 8, 179-193. http://dx.doi.org/10.1029/94GB00207.

Cavan, E.L., Le Moigne, F.A.C. Poulton, A.J., Tarling, G.A., Ward, P., Daniels, C.J., Fragoso, G., Sanders, R., 2015. Attenuation of particulate organic carbon flux in the Scotia Sea, Southern Ocean, is controlled by zooplankton fecal pellets. Geophys. Res. Lett., 821-830. http://dx.doi.org/10.1002/2014GL062744.

Cedhagen, T., Cheah, W., Bracher, A., Lejzerowicz, F., 2014. Algal pigments in Southern Ocean abyssal foraminiferans indicate pelagobenthic coupling. DeepSea Res. Part II Top. Stud. Oceanogr. 108, 27-32. http://dx.doi.org/10.1016/j. dsr2.2014.07.017.

Charette, M.A., Buesseler, K.O., 2000. Does iron fertilization lead to rapid carbon export in the Southern Ocean? Geochem. Geophys. Geosyst. 1, 1-7. http://dx. doi.org/10.1029/2000GC000069.

Cheah, W., Soppa, M.A., Wiegmann, S., Ossebaar, S., Laglera, L.M., Strass, V.H., Santos-Echeandía, J., Hoppema, M., Wolf-Gladrow, D., Bracher, A., 2017. Importance of deep-mixing and silicic acid in regulating phytoplankton biomass and composition in the iron-limited Antarctic Polar Front region in summer. Deep-Sea Res. Part II Top. Stud. Oceanogr., 138, 74-85. http://dx.doi. org/10.1016/j.dsr2.2016.05.019.

Cochran, J.K., Buesseler, K.O., Bacon, M.P., Wang, H.W., Hirschberg, D.J., Ball, L., Andrews, J., Crossin, G., Fleer, A., 2000. Short-lived thorium isotopes (Th-234, Th-228) as indicators of POC export and particle cycling in the Ross Sea,
Southern Ocean. Deep-Sea Res. Part II Top. Stud. Oceanogr. 47, 3451-3490. http: //dx.doi.org/10.1016/S0967-0645(00)00075-8.

Cochran, J.K., Masqué, P., 2003. Short-lived U/Th series radionuclides in the ocean tracers for scavenging rates, export fluxes and particle dynamics. Rev. Miner Geochem. 52, 461-492. http://dx.doi.org/10.2113/0520461.

Coppola, L., Roy-Barman, M., Mulsow, S., Povinec, P., Jeandel, C., 2005. Low particulate organic carbon export in the frontal zone of the Southern Ocean (Indian sector) revealed by ${ }^{234}$ Th. Deep-Sea Res. Part I Oceanogr. Res. Pap. 52, 51-68. http://dx.doi.org/10.1016/j.dsr.2004.07.020.

Ebersbach, F., Assmy, P., Martin, P., Schulz, I., Wolzenburg, S., Nöthig, E.-M., 2014 Particle flux characterisation and sedimentation patterns of protistan plankton during the iron fertilisation experiment LOHAFEX in the Southern Ocean. DeepSea Res. Part I Oceanogr. Res. Pap. 89, 94-103. http://dx.doi.org/10.1016/j. dsr.2014.04.007.

Ebersbach, F., Trull, T.W., 2008. Sinking particle properties from polyacrylamide gels during the KErguelen Ocean and Plateau compared Study (KEOPS): zooplankton control of carbon export in an area of persistent natural iron inputs in the Southern Ocean. Limnol. Oceanogr. 53, 212-224. http://dx.doi.org/10.4319/ lo.2008.53.1.0212.

Ebersbach, F. Trull, T.W. Davies, D.M., Bray, S.G., 2011. Controls on mesopelagic particle fluxes in the sub-Antarctic and Polar Frontal Zones in the Southern Ocean south of Australia in summer-perspectives from free-drifting sediment traps. Deep-Sea Res. Part II Top. Stud. Oceanogr. 58, 2260-2276. http://dx.doi. org/10.1016/j.dsr2.2011.05.025.

Fowler, S.W., Knauer, G.A., 1986. Role of large particles in the transport of elements and organic compounds through the oceanic water column. Prog. Oceanogr. 16, 147-194. http://dx.doi.org/10.1016/0079-6611(86)90032-7.

Giering, S.L.C., Sanders, R., Lampitt, R.S., Anderson, T.R., Tamburini, C., Boutrif, M., Zubkov, M.V., Marsay, C.M., Henson, S.A., Saw, K., Cook, K., Mayor, D.J., 2014 Reconciliation of the carbon budget in the ocean's twilight zone. Nature 507, 480-483. http://dx.doi.org/10.1038/nature13123.

Gruber, N., Gloor, M., Mikaloff Fletcher, S.E., Doney, S.C., Dutkiewicz, S., Follows, M. J., Gerber, M., Jacobson, A.R., Joos, F., Lindsay, K., Menemenlis, D., Mouchet, A. Müller, S.A., Sarmiento, J.L., Takahashi, T., 2009. Oceanic sources, sinks, and transport of atmospheric $\mathrm{CO}_{2}$. Glob. Biogeochem. Cycles 23, 1-21. http://dx.doi. org/10.1029/2008GB003349.

Guidi, L., Stemmann, L., Jackson, G.A., Ibanez, F., Claustre, H., Legendre, L., Picheral, M., Gorsky, G., 2009. Effects of phytoplankton community on production, size and export of large aggregates: a world-ocean analysis. Limnol. Oceanogr. 54 1951-1963. http://dx.doi.org/10.4319/lo.2009.54.6.1951.

Haskell, W.Z., Berelson, W.M. Hammond, D.E., Capone, D.G., 2013. Particle sinking dynamics and POC fluxes in the Eastern Tropical South Pacific based on ${ }^{234} \mathrm{Th}$ budgets and sediment trap deployments. Deep-Sea Res. Part I Oceanogr. Res. Pap. 81, 1-13. http://dx.doi.org/10.1016/j.dsr.2013.07.001.

Hauck, J., Völker, C., Wang, T., Hoppema, M., Losch, M., Wolf-Gladrow, D.A., 2013. Seasonally different carbon flux changes in the Southern Ocean in response to the southern annular mode. Glob. Biogeochem. Cycles 27, 1236-1245. http: //dx doi.org/10.1002/2013GB004600.

Henson, S.A., Yool, A., Sanders, R., 2015. Variability in efficiency of particulate organic carbon export: a model study. Glob. Biogeochem. Cycles 29, 33-45. http://dx.doi.org/10.1002/2014GB004965.

Hoppe, C.J.M., Klaas, C., Ossebaar, S., Soppa, M.A., Cheah, W., Laglera, L.M., SantosEcheandía, J., Rost, B., Wolf-Gladrow, D., Bracher, A., Hoppema, M., Strass, V.H. Trimborn, S., 2017. Controls of primary production in two phytoplankton blooms in the Antarctic Circumpolar Current. Deep-Sea Res. Part II Top. Stud. Oceanogr., 138, 63-73. http://dx.doi.org/10.1016/j.dsr2.2015.10.005.

Iversen, M.H., Klaas, C., 2013. Controls on the vertical fluxes of the Southern Ocean In: Dieter Wolf-Gladrow (Ed.), The Expedition of the Research Vessel "Polarstern" to the Antarctic in 2012 (ANT-XXVIII/3). Reports on Polar and Marine Research 661. Bremerhaven, pp. 70-74.

Iversen, M.H., Nowald, N., Ploug, H., Jackson, G.A., Fischer, G., 2010. High resolution profiles of vertical particulate organic matter export off Cape Blanc, Mauritania: degradation processes and ballasting effects. Deep-Sea Res. Part I Oceanogr. Res. Pap. 57, 771-784. http://dx.doi.org/10.1016/j.dsr.2010.03.007.

Iversen, M.H., Robert, M.L., 2015. Ballasting effects of smectite on aggregate formation and export from a natural plankton community. Mar. Chem. 175, 18-27. http://dx.doi.org/10.1016/j.marchem.2015.04.009.

Jacquet, S.H., Lam, P.J., Trull, T., Dehairs, F., 2011. Carbon export production in the subantarctic zone and polar front zone south of Tasmania. Deep-Sea Res. Part II Top. Stud. Oceanogr. 58, 2277-2292. http://dx.doi.org/10.1016/j.dsr2.2011.05.035.

Kiørbe, T., 2000. Colonization of marine snow aggregates by invertebrate zooplankton: abundance, scaling, and possible role. Limnol. Oceanogr. 45, 479-484. http://dx.doi.org/10.4319/lo.2000.45.2.0479.

Klaas, C., Archer, D.E., 2002. Association of sinking organic matter with various types of mineral ballast in the deep sea: implications for the rain ratio. Glob. Biogeochem. Cycles 16, 63-1-63-14. http://dx.doi.org/10.1029/2001GB001765.

Knap, A., Michaels, A., Close, A., Ducklow, H., Dickson, A., 1996. Protocols for the Joint Global Ocean Flux Study (JGOFS) Core Measurements. JGOFS Report No. 19.

Laurenceau-Cornec, E.C., Trull, T.W., Davies, D.M., Bray, S.G., Doran, J., Planchon, F. Carlotti, F., Jouandet, M.-P., Cavagna, A.-J., Waite, A.M., Blain, S., 2015. The relative importance of phytoplankton aggregates and zooplankton fecal pellets to carbon export: insights from free-drifting sediment trap deployments in naturally iron-fertilised waters near the Kerguelen Plateau. Biogeosciences 12, 1007-1027. http://dx.doi.org/10.5194/bg-12-1007-2015.

Le Moigne, F.A.C., Henson, S.A., Sanders, R.J., Madsen, E., 2013. Global database of surface ocean particulate organic carbon export fluxes diagnosed from the 
${ }^{234}$ Th technique. Earth Syst. Sci. Data 5, 295-304. http://dx.doi.org/10.5194/ essd-5-295-2013.

Le Moigne, F.A.C., Pabortsava, K., Marcinko, C.L.J., Martin, P., Sanders, R.J., 2014 Where is mineral ballast important for surface export of particulate organic carbon in the ocean? Geophys. Res. Lett., 1-9. http://dx.doi.org/10.1002/ 2014GL061678.

Leach, H., Strass, V.H., Prandke, H., 2017. Mixing and finescale structures in two mesoscale features of the Antarctic Circumpolar Current. Deep-Sea Res. Part II Top. Stud. Oceanogr., 138. 39-51. http://dx.doi.org/10.1016/j.dsr2.2015.10.006.

Maiti, K., Charette, M.A., Buesseler, K.O., Kahru, M., 2013. An inverse relationship between production and export efficiency in the Southern Ocean. Geophys. Res. Lett. 40, 1557-1561. http://dx.doi.org/10.1002/grl.50219.

Martin, P., Rutgers van der Loeff, M.M., Cassar, N., Vandromme, P., D'Ovidio, F. Stemmann, L., Rengarajan, R., Soares, M., González, H.E., Ebersbach, F., Lampitt, R.S., Sanders, R., Barnett, B.A., Smetacek, V., Naqvi, S.W.A., 2013. Iron fertilization enhanced net community production but not downward particle flux during the Southern Ocean iron fertilization experiment LOHAFEX. Glob. Biogeochem. Cycles 27, 871-881. http://dx.doi.org/10.1002/gbc.20077.

Morris, P.J., Sanders, R., Turnewitsch, R., Thomalla, S., 2007. ${ }^{234}$ Th-derived particulate organic carbon export from an island-induced phytoplankton bloom in the Southern Ocean. Deep-Sea Res. Part II Top. Stud. Oceanogr. 54, 2208-2232. http://dx.doi.org/10.1016/j.dsr2.2007.06.002.

OC-CCI, 2015. Ocean Color Climate Change Initiative Product User Guide Version 2 (Grant, M. , Jackson, T., Chuprin, A., Sathyendranath, S., Zühlke, M., Storm, T., Boettcher, M., Fomferra, N. (Eds.), (c) Plymouth Marine Laboratory).

Owens, S.A., 2013. Advances in Measurements of Particle Cycling and Fluxes in the Ocean. Massachusetts Institute of Technology and Woods Hole Oceanographic Institution, Woods Hole, MA. http://dx.doi.org/10.1575/1912/5746.

Owens, S.A., Buesseler, K.O., Sims, K.W.W., 2011. Re-evaluating the ${ }^{238}$ U-salinity relationship in seawater: implications for the ${ }^{238} \mathrm{U}-{ }^{234} \mathrm{Th}$ disequilibrium method. Mar. Chem. 127, 31-39. http://dx.doi.org/10.1016/j.marchem.2011.07.005.

Pike, S., Buesseler, K., Andrews, J., Savoye, N., 2005. Quantification of ${ }^{234}$ Th recovery in small volume sea water samples by inductively coupled plasma-mas spectrometry. J. Radioanal. Nucl. Chem. 263, 355-360. http://dx.doi.org 10.1007/s10967-005-0594-Z.

Planchon, F., Ballas, D., Cavagna, A.-J., Bowie, A.R., Davies, D., Trull, T., LaurenceauCornec, E.C., Van Der Merwe, P., Dehairs, F., 2015. Carbon export in the naturally iron-fertilized Kerguelen area of the Southern Ocean based on the ${ }^{234} \mathrm{Th}$ approach. Biogeosciences 12, 3831-3848. http://dx.doi.org/10.5194/ bg-12-3831-2015.

Planchon, F., Cavagna, A.-J., Cardinal, D., André, L., Dehairs, F., 2013. Late summer particulate organic carbon export and twilight zone remineralisation in the Atlantic sector of the Southern Ocean. Biogeosciences 10, 803-820. http://dx doi.org/10.5194/bg-10-803-2013.

Poulton, A.J., Mark Moore, C., Seeyave, S., Lucas, M.I., Fielding, S., Ward, P., 2007. Phytoplankton community composition around the Crozet Plateau, with emphasis on diatoms and Phaeocystis. Deep-Sea Res. Part II Top. Stud. Oceanogr. 54, 2085-2105. http://dx.doi.org/10.1016/j.dsr2.2007.06.005.

Puigcorbé, V., Benitez-Nelson, C.R., Masqué, P., Verdeny, E., White, A.E., Popp, B.N., Prahl, F.G., Lam, P.J., 2015. Small phytoplankton drive high summertime carbon and nutrient export in the Gulf of California and Eastern Tropical North Pacific. Glob. Biogeochem. Cycles 29, 1309-1332. http://dx.doi.org/10.1002/2015GB005134.

Puigcorbé, V., Roca-Martí, M., Masqué, P., Benitez-Nelson, C.R., Rutgers van der Loeff, M.M., Laglera, L.M., Bracher, A., Cheah, W., Strass, V.H., Hoppema, M., SantosEcheandía, J., Klaas, C., 2017. Particulate organic carbon export across the Antarctic Circumpolar Current at $10^{\circ} \mathrm{E}$ : differences between north and south of the Antarctic Polar Front. Deep-Sea Res. Part II Top. Stud. Oceanogr., 138, 86-101. http://dx.doi.org/10.1016/j.dsr2.2016.05.016.

Quéguiner, B., 2013. Iron fertilization and the structure of planktonic communities in high nutrient regions of the Southern Ocean. Deep-Sea Res. Part II Top. Stud. Oceanogr. 90, 43-54. http://dx.doi.org/10.1016/j.dsr2.2012.07.024.

Resplandy, L., Martin, A.P., Le Moigne, F., Martin, P., Aquilina, A., Mémery, L., Lévy, M., Sanders, R., 2012. How does dynamical spatial variability impact ${ }^{234} \mathrm{Th}$ derived estimates of organic export? Deep-Sea Res. Part I Oceanogr. Res. Pap. 68, 24-45. http://dx.doi.org/10.1016/j.dsr.2012.05.015.

Rutgers van der Loeff, M.M., Buesseler, K.O., Bathmann, U., Hense, I., Andrews, J. 2002. Comparison of carbon and opal export rates between summer and spring bloom periods in the region of the Antarctic Polar Front, SE Atlantic. Deep-Sea Res. Part II Top. Stud. Oceanogr. 49, 3849-3869. http://dx.doi.org/10.1016 S0967-0645(02)00114-5.

Rutgers van der Loeff, M.M., Cai, P., Stimac, I., Bracher, A., Middag, R., Klunder, M. Van Heuven, S., 2011. ${ }^{234} \mathrm{Th}$ in surface waters: distribution of particle export flux across the Antarctic Circumpolar Current and in the Weddell Sea during the GEOTRACES expedition ZERO and DRAKE. Deep-Sea Res. Part II Top. Stud. Oceanogr. 58, 2749-2766. http://dx.doi.org/10.1016/j.dsr2.2011.02.004.

Rutgers van der Loeff, M.M., Friedrich, J., Bathmann, UV., 1997. Carbon export during the Spring Bloom at the Antarctic Polar Front, determined with the natural tracer ${ }^{234}$ Th. Deep-Sea Res. Part II Top. Stud. Oceanogr. 44, 457-478. http://dx.doi.org/10.1016/S0967-0645(96)00067-7.

Rutgers van der Loeff, M.M., Sarin, M.M., Baskaran, M., Benitez-Nelson, C., Buesseler K.O., Charette, M., Dai, M., Gustafsson, Ö., Masqué, P., Morris, P.J., Orlandini, K., Rodriguez y Baena, A., Savoye, N., Schmidt, S., Turnewitsch, R., Vöge, I., Waples, J.T. 2006. A review of present techniques and methodological advances in analyzing ${ }^{234}$ Th in aquatic systems. Mar. Chem., 100; , pp. 190-212. http://dx. doi.org/10.1016/j.marchem.2005.10.012.

Rutgers van der Loeff, M.M., Vöge, I., 2001. Does Fe fertilisation enhance the export production as measured through the ${ }^{234} \mathrm{Th} /{ }^{238} \mathrm{U}$ disequilibrium in surface water? In: Victor Smetacek, Ulrich Bathmann, Saad EI Naggar (Eds.), The expeditions ANTARKTIS XVIII/1-2 of the research vessel "Polarstern" in 2000. Reports on Polar and Marine Research 400. Bremerhaven, pp. 222-225.

Salter, I., Lampitt, R.S., Sanders, R., Poulton, A., Kemp, A.E.S., Boorman, B., Saw, K. Pearce, R., 2007. Estimating carbon, silica and diatom export from a naturally fertilised phytoplankton bloom in the Southern Ocean using PELAGRA: a nove drifting sediment trap. Deep-Sea Res. Part II Top. Stud. Oceanogr. 54, 2233-2259. http://dx.doi.org/10.1016/j.dsr2.2007.06.008.

Savoye, N., Benitez-Nelson, C., Burd, A.B., Cochran, J.K., Charette, M., Buesseler, K.O., Jackson, G.A., Roy-Barman, M., Schmidt, S., Elskens, M., 2006. ${ }^{234}$ Th sorption and export models in the water column: a review. Mar. Chem. 100, 234-249. http://dx.doi.org/10.1016/j.marchem.2005.10.014.

Savoye, N., Buesseler, K.O., Cardinal, D., Dehairs, F., 2004. ${ }^{234}$ Th deficit and excess in the Southern Ocean during spring 2001: Particle export and remineralization. Geophys. Res. Lett. 31, L12301. http://dx.doi.org/10.1029/2004GL019744.

Savoye, N., Trull, T.W., Jacquet, S.H.M., Navez, J., Dehairs, F., 2008. ${ }^{234}$ Th-based export fluxes during a natural iron fertilization experiment in the Southern Ocean (KEOPS). Deep-Sea Res. Part II Top. Stud. Oceanogr. 55, 841-855. http: //dx.doi.org/10.1016/j.dsr2.2007.12.036.

Schlitzer, R., 2002. Carbon export fluxes in the Southern Ocean: results from inverse modeling and comparison with satellite-based estimates. Deep-Sea Res. Part II Top. Stud. Oceanogr. 49, 1623-1644. http://dx.doi.org/10.1016/ S0967-0645(02)00004-8.

Smetacek, V., 1999. Diatoms and the ocean carbon cycle. Protist 150, 25-32. http: //dx.doi.org/10.1016/S1434-4610(99)70006-4.

Smetacek, V., Klaas, C., Strass, V.H., Assmy, P., Montresor, M., Cisewski, B., Savoye, N., Webb, A., D’Ovidio, F., Arrieta, J.M., Bathmann, U., Bellerby, R., Berg, G.M., Croot, P., Gonzalez, S., Henjes, J., Herndl, G.J., Hoffmann, L.J., Leach, H., Losch, M., Mills, M.M., Neill, C., Peeken, I., Röttgers, R., Sachs, O., Sauter, E., Schmidt, M.M., Schwarz, J., Terbrüggen, A., Wolf-Gladrow, D., 2012. Deep carbon export from a Southern Ocean iron-fertilized diatom bloom. Nature 487, 313-319. http://dx. doi.org/10.1038/nature11229.

Smith, D.C., Simon, M., Alldredge, A.L., Azam, F., 1992. Intense hydrolytic enzyme activity on marine aggregates and implications for rapid particle dissolution. Nature 359, 139-142. http://dx.doi.org/10.1038/359139a0.

Strass, V.H., Leach, H., Prandke, H., Donnelly, M., Bracher, A., Wolf-Gladrow, D., 2017. The physical environmental conditions for biogeochemical differences along the Antarctic Circumpolar Current in the Atlantic Sector during late austral summer 2012. Deep-Sea Res. Part II Top. Stud. Oceanogr., 138,6-25. http://dx. doi.org/10.1016/j.dsr2.2016.05.018.

Takahashi, T., Sutherland, S.C., Sweeney, C., Poisson, A., Metzl, N., Tilbrook, B., Bates, N., Wanninkhof, R., Feely, R.A., Sabine, C., Olafsson, J., Nojiri, Y., 2002. Global sea-air $\mathrm{CO}_{2}$ flux based on climatological surface ocean $\mathrm{pCO}_{2}$, and seasonal biological and temperature effects. Deep-Sea Res. Part II Top. Stud. Oceanogr. 49, 1601-1622. http://dx.doi.org/10.1016/S0967-0645(02)00003-6.

Turner, J.T., 2015. Zooplankton fecal pellets, marine snow, phytodetritus and the ocean's biological pump. Prog. Ocean. 130, 205-248. http://dx.doi.org/10.1016/j. pocean.2014.08.005.

Uitz, J., Claustre, H., Griffiths, F.B., Ras, J., Garcia, N., Sandroni, V., 2009. A phytoplankton class-specific primary production model applied to the Kerguelen Islands region (Southern Ocean). Deep-Sea Res. Part I Oceanogr. Res. Pap. 56, 541-560. http://dx.doi.org/10.1016/j.dsr.2008.11.006.

Usbeck, R., Rutgers van der Loeff, M.M., Hoppema, M., Schlitzer, R., 2002. Shallow remineralization in the Weddell Gyre. Geochem. Geophys. Geosyst. 3, 1-18. http://dx.doi.org/10.1029/2001GC000182.

Wolf-Gladrow, D., 2013. The Expedition of the Research Vessel "Polarstern" to the Antarctic in 2012 (ANT-XXVIII/3). Reports on Polar and Marine Research 661. Bremerhaven, pp. 191

Wright, S.W., van den Enden, R.L., Pearce, I., Davidson, A.T., Scott, F.J., Westwood, K. J., 2010. Phytoplankton community structure and stocks in the Southern Ocean $\left(30-80^{\circ} \mathrm{E}\right)$ determined by CHEMTAX analysis of HPLC pigment signatures. Deep-Sea Res. Part II Top. Stud. Oceanogr. 57, 758-778. http://dx.doi.org/ 10.1016/j.dsr2.2009.06.015. 